\title{
The independence of phonology and morphology: the Celtic mutations*
}

\author{
Antony Dubach Green \\ University of Potsdam \\ green@ling.uni-potsdam.de
}

\begin{abstract}
One of the most important insights of Optimality Theory (Prince \& Smolensky 1993) is that phonological processes can be reduced to the interaction between faithfulness and universal markedness principles. In the most constrained version of the theory, all phonological processes should be thus reducible. This hypothesis is tested by alternations that appear to be phonological but in which universal markedness principles appear to play no role. If we are to pursue the claim that all phonological processes depend on the interaction of faithfulness and markedness, then processes that are not dependent on markedness must lie outside phonology. In this paper I will examine a group of such processes, the initial consonant mutations of the Celtic languages, and argue that they belong entirely to the morphology of the languages, not the phonology.
\end{abstract}

\section{$1 \quad$ Celtic consonant mutations}

The initial consonant mutations of the Celtic languages are of great interest in theoretical linguistics because they appear to be (and are frequently argued to be) phonological rules that apply in morphosyntactic rather than phonological environments. Within phonological theory they are interesting also because many of the individual mutations have different effects on different classes of sounds. Thus, for example, Eclipsis in Irish voices voiceless stops (e.g. p $\square$ b) and nasalizes voiced stops (e.g. b $\square$ m). The Soft Mutation in Welsh voices voiceless stops (e.g. p $\square$ b) and spirantizes voiced stops (e.g. b $\square$ v). The processes are thus not uniform and only partially predictable. In derivational phonology, devising phonological rules to account for the mutations is challenging, but not impossible. Derivational phonology allows its rules to be arbitrary and independent of universal markedness principles. But the advent of OT has forced a rethinking of the nature of phonological processes: according to the new theory, phonological processes are predicted to result from the interaction of markedness and faithfulness. In this paper I will argue that since the morphosyntactically conditioned consonant mutations of Celtic do not result from that interaction, they cannot be phonological. Instead, the mutations are best regarded as being exclusively in the domain of the morphology, not the phonology at all. I will argue that, like inflected forms, mutated forms are listed separately in a word-based lexicon as allomorphs, and that the selection of mutated allomorphs is determined by a form of government similar to that determining the distribution of Case.

* Portions of this paper were presented at the Fourth Celtic Linguistics Conference in Cambridge in September 2003. This paper is a preliminary version of a chapter to appear in Green (in preparation). I would like to thank audience members at CLC4 as well as Laura Downing and Caroline Féry for helpful comments and suggestions. 


\subsection{The effects of the mutations}

The effects of the mutations vary from language to language. For example, as shown in (1), Irish has two mutations, Lenition and Eclipsis. Lenition in Irish changes stops and $\mathrm{m}$ into continuants (fricatives or glides), and deletes f; $s$ is debuccalized to $h$, but only before vowels and coronal sonorants (before $\mathrm{m}$ and obstruents $\mathrm{s}$ is unaffected by Lenition). The coronals $\mathrm{t}$ and d also undergo debuccalization, becoming h and $\mathrm{C}$ respectively (see Ní Chiosáin 1991, $27 \mathrm{f}$. for a discussion of why d $\square$ is to be considered debuccalization). In many dialects, the "tense sonorants" $\mathrm{L}$ and $\mathrm{N}$ become lenited to their "lax" counterparts 1 and $\mathrm{n} .{ }^{1}$ Vowels are not affected by Lenition, nor, in most dialects, is $\mathrm{r}^{2}{ }^{2}$ Eclipsis changes voiceless stops and $\mathrm{f}$ into their voiced counterparts, changes voiced stops into the corresponding nasals, and attaches $\mathrm{n}$ to vowel-initial words. Sonorant consonants are not affected by Eclipsis, nor is $\mathrm{s}$ in most dialects. ${ }^{3}$ In the orthography, Lenition of obstruents and $\mathrm{m}$ is indicated by placing an $\mathrm{h} \square$ after the first letter; Lenition of 1 and $n$ is not shown. Eclipsis is shown orthographically by placing the letter of the mutated consonant before that of the radical (unmutated) consonant.

(1) Irish (Cワstands for a phonemically palatalized C)

[phonemic transcription], Ðrthographic representation!

\begin{tabular}{|c|c|c|}
\hline Radical form & Lenition & Eclipsis \\
\hline$[\mathrm{p}, \mathrm{p} \square \square \square$ & {$[\mathrm{f}, \mathrm{f}]\lceil\mathrm{ph} \square$} & {$[\mathrm{b}, \mathrm{b}]$ bp $\square$} \\
\hline$[\mathrm{t}, \mathrm{t} \square \mathrm{t \square}$ & {$[\mathrm{h}, \mathrm{h} \sim \mathrm{x} \square$ th $\square$} & {$[\mathrm{d}, \mathrm{d}] \square \mathrm{dt} \square$} \\
\hline$[\mathrm{k}, \mathrm{k} \square \boxminus \square$ & {$[\mathrm{x}, \mathrm{x} \square \notin \mathrm{h} \square$} & {$[\mathrm{g}, \mathrm{g}] \mathrm{gc} \square$} \\
\hline$[\mathrm{b}, \mathrm{b} \square \square \square$ & {$[\mathrm{w} \sim \mathrm{v}, \mathrm{v} \square \square \mathrm{h} \square$} & {$[\mathrm{m}, \mathrm{m} \square \square \mathrm{mb} \square$} \\
\hline$[\mathrm{d}, \mathrm{d} \square \square \mathrm{d}$ & 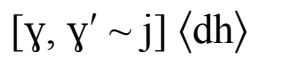 & {$[\mathrm{N}, \mathrm{N} \square \square \mathrm{hd} \square$} \\
\hline$[\mathrm{g}, \mathrm{g}] \mathrm{g} \square$ & {$[\mathrm{Q}, \mathrm{Q} \square \sim \mathrm{j}] \mathrm{gh} \square$} & {$[\mathrm{C}, \mathrm{Q}] \mathrm{Gg} \square$} \\
\hline [f, f口扣 & $\varnothing$ th $\square$ & {$[\mathrm{w} \sim \mathrm{v}, \mathrm{v} \square$ ఏhf $\square$} \\
\hline [s, s]\$口 & {$[\mathrm{h}, \mathrm{h} \sim \mathrm{x} \square \not \mathrm{h} \square$} & no change \\
\hline$[\mathrm{m}, \mathrm{m} \square \square \mathrm{m} \square$ & {$[\mathrm{w} \sim \mathrm{v}, \mathrm{v} \square \square \mathrm{mh} \square$} & no change \\
\hline [N, N口G] & {$[\mathrm{n}, \mathrm{n} \square[\mathrm{n} \square$} & no change \\
\hline 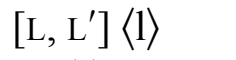 & {$[1,1 \square \square \square$} & no change \\
\hline [r] G] & no change & no change \\
\hline vowel & no change & {$[\mathrm{N}]$ or $[\mathrm{N} \square[\mathrm{h}-\square+$ vowel } \\
\hline
\end{tabular}

As shown in (2), Welsh has three mutations: Soft Mutation (also called Lenition; abbreviated $\mathrm{SM}$ ), Nasal Mutation (NM), and Aspirate Mutation (more accurately called Spirantization; abbreviated AM). SM voices voiceless stops and liquids, spirantizes b, d, m, and deletes $\mathrm{g}$. SM does not affect voiceless fricatives, $n$, or $j$. NM converts voiceless stops into voiceless nasals and voiced stops into plain nasals; it does not affect other sounds. AM converts voiceless stops into fricatives and does not affect other sounds.

1 The Lenition of 1 and $\mathrm{n}$ sounds is described for the dialects of Aran (Finck 1899), Erris (Mhac an Fhailigh 1968), and Cois Fhairrge (de Bhaldraithe 1945/1975, 1953/1977) in the west and of Meenawannia (Quiggin 1906), The Rosses (Ó Searcaigh 1925), South Armagh (Sommerfelt 1929), Torr (Sommerfelt 1965), and Tangaveane/Commeen (Hughes 1986) in the north. Many fieldworkers in the first half of the twentieth century found a contrast between lenited and unlenited 1 and $n$ sounds only among older speakers; it may be nearly extinct today.

2 Ó Siadhail (1989: 112) reports that some speakers from the south use palatalized $\mathrm{r} \square$ as the lenited correspondent of $r$.

3 There are dialects of Irish where $\mathrm{z}$ is found as the Eclipsis correspondent of s (Ó Siadhail 1989: 114). 
(2) Welsh

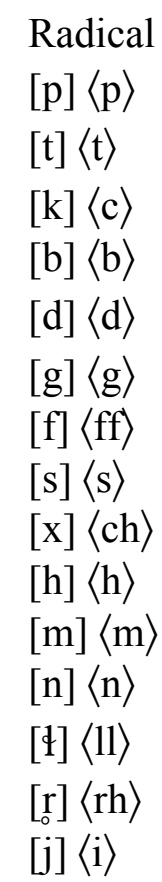

SM

[b] நए

[d] $\mathrm{d} \square$

[g] [g

[v] fD

[प] ॠdd $\square$

$\varnothing \square \square$

no change

no change

no change

no change

[v] t]

no change

[1] ㅁ

[r] tr

no change
NM

$[\mathrm{m} \rrbracket[\mathrm{mh} \square$

$[\mathrm{n} \rrbracket \mathrm{hh} \square$

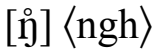

[m] $[\mathrm{m} \square$

[n] [n厂

[] [ng

no change

no change

no change

no change

no change

no change

no change

no change

no change
AM

[f] [ph $\square$

[ए] th $\square$

[x] [h]

no change

no change

no change

no change

no change

no change

no change

no change

no change

no change

no change

no change

Consonant mutations are found in the other Insular Celtic languages as well: Scots Gaelic, Breton, Cornish, and Manx (discussed below).

\subsection{The environments of the mutations}

The environments in which the various mutations are found are not phonological but morphosyntactic. Most cases of mutation are found on a lexical word either when this is preceded by a function word (proclitic-triggered mutation) or when it occurs in a specific syntactic environment (syntax-triggered mutation). The environments for the mutations are extremely varied, arbitrary, and unpredictable, and are often subject to dialectal variation.

For example, in both Irish and Welsh, nouns are sometimes mutated after the definite article. ${ }^{4}$ In Welsh (3), SM is found only when the noun is feminine singular (except that $\square$ and rbare not mutated here); in other cases the radical form is used. For reference, the radical form is listed on the right.

(3) Mutations of nouns after the definite article in Welsh

$\begin{array}{lllll}\text { Masc. sing. } & \text { Radical } & \text { y bardd } & \text { 'the poet' } & \\ \text { Fem. sing. } & \text { SM } & \text { y faner } & \text { 'the flag' } \\ \text { Plural } & \text { Radical } & \text { y beirdd } & \text { 'the poets' } & \text { (baner) } \\ & & \text { y baneri } & \text { 'the flags' }\end{array}$

In Irish the situation is more complicated, partly because Irish nouns are inflected for case. In the singular, masculine nouns after the definite article are not mutated in the nominative, but undergo Lenition in the genitive. With feminine nouns it is exactly reversed: they undergo Lenition in the nominative after the definite article, but take the radical form in the genitive. Singular nouns of both genders undergo Lenition in the dative after the definite article when governed by one of the prepositions $d e$ 'from', do 'to', or $i$ 'in', and either Lenition or Eclipsis

4 In what follows, most Irish examples are from Christian Brothers (1960), Ó Dónaill (1977), or the Tobar na Gaedhilge database (Ó Duibhín 2003). Most Welsh examples are from King (1993) or Thorne (1993). 
(depending on dialect) when governed by any other preposition taking the dative. ${ }^{5}$ In the plural (of both genders) the radical is used in the nominative and dative after the definite article, but there is Eclipsis in the genitive. Examples are shown in (4).

(4) Mutations of nouns after the definite article in Irish

\begin{tabular}{|c|c|c|c|c|}
\hline Masc. nom. sing. & Radical & an fear & 'the man' & \multirow{3}{*}{$\begin{array}{l}\text { (fir) } \\
\text { (bróg) }\end{array}$} \\
\hline Masc. gen. sing. & Lenition & an fhir & 'of the man' & \\
\hline Fem. nom. sing. & Lenition & an bhróg & 'the shoe' & \\
\hline Fem. gen. sing. & Radical & na bróige & 'of the shoe' & \multirow{5}{*}{$\begin{array}{l}\text { (fear) } \\
\text { (bróg) } \\
\text { (crann) } \\
\text { (fear) }\end{array}$} \\
\hline \multirow[t]{5}{*}{ Dat. sing. } & \multirow{3}{*}{$\begin{array}{l}\text { Lenition after } \\
\text { de 'from', do } \\
\text { 'to', } i \text { 'in' }\end{array}$} & den fhear & 'from the man' & \\
\hline & & don bhróg & 'to the shoe' & \\
\hline & & sa chrann & 'in the tree' & \\
\hline & \multirow{2}{*}{$\begin{array}{l}\text { Lenition or } \\
\text { Eclipsis (ac- } \\
\text { cording to } \\
\text { dialect) after } \\
\text { other } \\
\text { prepositions }\end{array}$} & $\begin{array}{l}\text { ag an fhear/ } \\
\text { ag an bhfear }\end{array}$ & 'at the man' & \\
\hline & & $\begin{array}{l}\text { faoin bhróg/ } \\
\text { faoin mbróg }\end{array}$ & 'under the shoe' & \multirow[t]{3}{*}{ (bróg) } \\
\hline \multirow[t]{2}{*}{ Nom. plural } & \multirow[t]{2}{*}{ Radical } & na fir & 'the men' & \\
\hline & & na bróga & 'the shoes' & \\
\hline \multirow[t]{2}{*}{ Gen. plural } & \multirow[t]{2}{*}{ Eclipsis } & na bhfear & 'of the men' & \multirow{4}{*}{$\begin{array}{l}\text { (fear) } \\
\text { (bróg) }\end{array}$} \\
\hline & & na mbróg & 'of the shoes' & \\
\hline \multirow[t]{2}{*}{ Dat. plural } & \multirow[t]{2}{*}{ Radical } & do na fir & 'to the men' & \\
\hline & & $\begin{array}{l}\text { faoi na } \\
\text { bróga }\end{array}$ & 'under the shoes' & \\
\hline
\end{tabular}

The coronal stops $\mathrm{t}, \mathrm{d}$ do not undergo Lenition after the definite article: an $\boldsymbol{t} i$ ' of the house' (masc. gen. sg.), an deoir 'the tear' (fem. nom. sg.). The coronal fricative s is lenited after the definite article not to $\mathrm{h}$ (as usual), but rather to $\mathrm{t}$ (orthographic [ts], as shown in (5).

(5) Lenition of s to $\mathrm{t} \llbracket \mathrm{ts} \square$

\begin{tabular}{|c|c|c|}
\hline $\begin{array}{l}\text { an tsagairt } \\
\text { an tsúil }\end{array}$ & $\begin{array}{l}{[\square \mathrm{n} \text { tag } \square \mathrm{rt} \square} \\
{[\square \mathrm{n} \text { tu: } 1]}\end{array}$ & $\begin{array}{l}\text { 'of the priest' (masc. gen. sg.) } \\
\text { 'the eye' (fem. nom. sg.) }\end{array}$ \\
\hline
\end{tabular}

Since this is phonologically a fortition, it can be seen that the morphological Lenition mutation is not always manifested by phonological weakening.

Vowel-initial nouns are incapable of undergoing Lenition, but rather mark its absence in the places where consonant-initial nouns take the radical form. In the masculine nominative singular, a vowel-initial noun acquires a prothetic $t$ after the definite article, see (6a), while in the feminine genitive singular and in the plural a vowel-initial noun acquires a prothetic $h$ after the definite article, as in (6a) and (6b).

(6) Vowel-initial nouns in nonleniting contexts after the definite article
a. an t-asal
'the donkey'
(asal)
b. na heaglaise
'of the church'
c. na héin
'the birds'
(eaglaise)
(éin)

With a few lexicalized exceptions, a noun in the standard language has the same form in the dative as in the nominative, except for the different mutation effect after the definite article. In Irish, the dative is found only in conjunction with a preposition (but not all prepositions govern the dative). 
A complete list of environments where the mutations are found would not only go beyond the bounds of this paper, it would distract from the point, which is simply that the mutations are found in a wide variety of unrelated environments, and no broad generalizations can be made about where which mutation occurs, either in Irish or in Welsh (or indeed in any of the other Celtic languages). The interested reader may refer to the Appendix for lists, with examples, of other environments in which various words undergo mutation in Irish and Welsh.

That the environments of the mutations are nonphonological is not controversial. But in this paper I will argue that the mutation processes are not phonological either, which frees the analysis from the restrictions imposed by phonology and acknowledges that the mutations are arbitrary in occurrence and only partially predictable in form. This point is illustrated in $\S 2$, where the nonphonological Lenition mutation is contrasted with a truly phonological lenition process in Manx, a language closely related to Irish. In $\$ 3$ I discuss further evidence against a phonological analysis and in $\$ 4$ I propose a morphological analysis assuming a word-based lexicon in which the mutated forms of words are listed as allomorphs. $\$ 5$ concludes the paper.

\section{$2 \quad$ Manx}

\subsection{Morphosyntactically triggered Lenition}

Manx (Jackson 1955, Broderick 1984-86), a now extinct ${ }^{6}$ close relative of Irish, had a single initial consonant mutation, namely Lenition, which was however only sporadically used in the spoken language, and mostly only in fixed expressions. The original effects (as attested primarily in Literary Manx) of this morphosyntactically triggered Lenition (abbreviated ML) are comparable to those of Irish illustrated above in (1); the effects in Manx are shown in (7).

\section{(7) Effects of ML in Manx}

$\begin{array}{ll}\text { Radical } & \text { Lenition } \\ \mathrm{p} & \mathrm{f} \\ \mathrm{t}, \mathrm{t} \square & \mathrm{h} \sim \mathrm{x}, \mathrm{h} \sim \mathrm{x} \square \\ \mathrm{k}, \mathrm{k} \square & \mathrm{h} \sim \mathrm{x}, \mathrm{h} \sim \mathrm{x} \square \\ \mathrm{b} & \mathrm{w} \sim \mathrm{v} \\ \mathrm{d}, \mathrm{d} \square & \mathrm{\square}, \mathrm{j} \\ \mathrm{g}, \mathrm{g} \square & \mathrm{\square}, \mathrm{j} \\ \mathrm{f} & \varnothing \\ \mathrm{s}, \mathrm{s} \square & \mathrm{h}, \mathrm{h} \sim \mathrm{x} \square \\ \mathrm{m} & \mathrm{w} \sim \mathrm{v} \\ \mathrm{n}, \mathrm{n} \square & \text { no change } \\ \mathrm{l}, \mathrm{l} \square & \text { no change } \\ \mathrm{r} & \text { no change } \\ \text { vowel } & \text { no change }\end{array}$

The environments where ML is found in Manx are also largely comparable to the environments where Lenition is found in Irish, although in the late spoken language Lenition was probably absent more often than present in most of these environments.

6 The last native speaker of Manx died in 1974; the last semi-native speaker in 1985. 
(8) Some environments of ML in Manx

feminine singular nouns after the definite article

Un vedn 'the woman'

(bedn)

nouns after certain (not all) possessive pronouns

$\mathrm{m} \square \mathrm{xre:wDn} \quad$ 'my bones' (kre:wDn)

nouns after certain numerals

de: fe:t四 'two children' (pe:t四)

nouns after certain prepositions

d $\square$ पulis $\square \quad$ 'to Douglas' (dulis

dative singular nouns after article

sDxa:rt 'in the cart'

adjectives after feminine singular nouns

iris $\square$ vai 'good weather'

(mai)

verbs in the past tense

vris $\square$ 'broke'

(bris】

An OT analysis assuming that ML is part of the phonology of Manx would have to show that there are circumstances under which the unfaithful correspondence relationships $/ \mathrm{b} / \quad[\mathrm{v}]^{7}, / \mathrm{k} /$

$[\mathrm{x}], / \mathrm{p} / \quad[\mathrm{f}], / \mathrm{d} / \quad[\mathrm{b}], / \mathrm{m} / \quad[\mathrm{v}]$, etc., are more harmonic than the faithful relationships $/ \mathrm{b} /$

[b], etc., as well as other possible unfaithful relationships including /d/ [0] and /t/ [0]. In principle, such an analysis could certainly be made to work, but, as we shall see in the next section, it will be difficult to maintain in the light of the phonologically triggered (specifically, intervocalic) lenition also found in Manx.

\subsection{Phonological lenition}

The phonology of late spoken Manx included a variable process of intervocalic lenition of obstruents. $^{8}$ Voiceless obstruents were voiced and stops (whether originally voiced or voiceless) were spirantized; underlyingly voiceless stops could undergo both changes. The effects of this process, which I will call Phonological Lenition or PL, are shown in (9) and examples are shown in (10). Crucially, the effects of PL are different from the effects of ML, with the exception of the voiced stops. While under ML voiceless stops remain voiceless but must become fricatives, under PL voiceless stops must become voiced but may remain stops. Also the fricatives $\mathrm{s}, \mathrm{x}$ become voiced under PL, while under ML $\mathrm{s}$ debuccalizes to $\mathrm{h}$ and $\mathrm{x}$ is not affected.

(9) Effects of Phonological Lenition (PL) in Manx (domain: word-internal V_V; optional)

$$
\begin{aligned}
& \mathrm{p}>\mathrm{b} \sim \mathrm{v} \quad \mathrm{b}>\mathrm{v} \\
& \mathrm{t}>\mathrm{d} \sim \mathrm{a} \quad \mathrm{d}>\mathrm{q} \\
& \mathrm{k}>\mathrm{g} \sim \mathrm{g} \quad \mathrm{g}>\mathrm{\textrm {C }}>\mathrm{\textrm {C }} \sim \mathrm{h} \sim \varnothing
\end{aligned}
$$

7 The notation $/ \square / \quad[\square]$ stands for "the input $\square$ stands in a correspondence relationship with the output $\square$." See McCarthy \& Prince (1999) for the nature of correspondence relationships.

8 There are some examples of $b$ and $d$ being spirantized in word-initial position as well. 
(10) Examples of intervocalic PL

\begin{tabular}{|c|c|}
\hline tapi $\sim$ tabi $\sim$ tavi & 'quick' \\
\hline bratag $\sim$ bradag $\sim$ bra $\square$ ag & ‘flag’' \\
\hline fi:kDl fi:gDl fi:पDl & 'tooth' \\
\hline $\mathrm{t}[1 \mathrm{~b} \mathrm{~b} \square \mathrm{rt} \sim \mathrm{t}[1 \mathrm{l} \mathrm{v} \square \mathrm{rt}$ & 'a well' \\
\hline $\mathrm{ed} \square \mathrm{n} \sim \mathrm{e}[\overline{\mathrm{n}}$ & 'face' \\
\hline $\operatorname{rug} \square \mathrm{t} \sim \mathrm{ru} \square[\mathrm{t}$ & ‘born’ \\
\hline e:s $\square \mathrm{n} \sim$ pre:zDn $\sim$ pre:[Dn & 'potatoes' \\
\hline le:xDn le::Dn le:hDn le::nn & 'days' \\
\hline
\end{tabular}

The first problem encountered in an analysis of PL is the variability of the process. Boersma (1998) has argued that free variation is analyzable in terms of stochastic constraint ranking, where each constraint has a range along a spectrum in which it applies. If two constraints are close to each other, their ranges may overlap, resulting in variable ranking between them: when constraint $\mathrm{A}$ and constraint $\mathrm{B}$ overlap, sometimes the ranking will be $\mathrm{A} \gg \mathrm{B}$ and sometimes it will be $\mathrm{B} \gg \mathrm{A}$. A full analysis of PL would have to take the variation into consideration, but the point of this paper is not to analyze PL but rather to show that only PL but not ML is part of the phonology of Manx. Therefore, for the sake of simplicity I will assume a variety of Manx where only the voiced fricative outputs are optimal.

Assuming that voiceless stops in the input correspond to voiced fricatives in the output when in intervocalic position, the constraints necessary to an analysis are the faithfulness constraints on voicing IDENT(voi), on continuity IDENT(cont), and on place IDENT(lab), IDENT(cor), IDENT(dor), as well as the markedness constraints *V[ $[$ voi] $\mathrm{V}$ (no voiceless sound between two vowels) and *V[ $[$ cont $] \mathrm{V}$ (no noncontinuant sound between two vowels). As shown in (11) - (13), the faithfulness constraints for place are high ranking, as are the two markedness constraints. The faithfulness constraints for voicing and continuity are ranked low.

\begin{tabular}{|r||c:c:c|c:c|}
\hline /tapi/ & IDENT(lab) & $* \mathrm{~V}[\square$ voi $] \mathrm{V}$ & $* \mathrm{~V}[\square$ cont] & IDENT(voi) & IDENT(cont) \\
\hline \hline tapi & & $* !$ & $*$ & & \\
\hline tabi & & & $* !$ & $*$ & \\
\hline tavi & & & & $*$ & $*$ \\
\hline tafi & & $* !$ & & & $*$ \\
\hline tahi & $* !$ & $*$ & & & $*$ \\
\hline
\end{tabular}

Since coronals are not debuccalized under PL, as they are under ML, the high rank of IDENT(cor) in Manx phonology is established, as shown in (12) - (13). 
$\mathrm{t} \square \square$ not $\mathrm{h}$ in PL (cf. $\mathrm{t} \square \mathrm{h}$ in $\mathrm{ML}$ )

\begin{tabular}{|r||c:c:c|c:c|c|}
\hline /bratag/ & IDENT(cor) & $* \mathrm{~V}[\square$ voi] & $* \mathrm{~V}[\square$ cont $] \mathrm{V}$ & IDENT(voi) & $\begin{array}{l}\text { IDENT } \\
\text { (cont) }\end{array}$ & $* \square$ \\
\hline \hline bratag & & $* !$ & $*$ & & & \\
\hline bradag & & & $* !$ & $*$ & & \\
\hline braDag & & & & $*$ & $*$ & $*$ \\
\hline brahag & $* !$ & $*$ & & & $*$ & \\
\hline
\end{tabular}

$$
\mathrm{d} \square \mathrm{Q} \text { not } \mathrm{i} \text { in PL (cf. d } \square \text { in ML) }
$$

\begin{tabular}{|r||c:c|c|c|}
\hline$/$ edDn/ & IDENT(cor) & $* V[\square$ cont] & IDENT(cont) & $* \square$ \\
\hline edDn & & $* !$ & & \\
\hline $\mathrm{e}$ [Dn & & & $*$ & $*$ \\
\hline $\mathrm{e}$ [Dn & $* !$ & & $*$ & \\
\hline
\end{tabular}

In the case of $\mathrm{s}$, the constraint $* \mathrm{~V}[\square$ cont $] \mathrm{V}$ is irrelevant since it is not violated by the candidate that is completely faithful to the input. The result is that no plausible candidate will violate it either, so that IDENT(cont) becomes irrelevant as well. What is interesting in this case is the apparent free variation between $\mathrm{C}$ and $\mathrm{z}$ in the output. As mentioned above, a convenient method of analyzing free variation in OT is through stochastic constraint ranking. In the case at hand, we may say that a markedness constraint banning $\mathrm{Q}$ and one banning $\mathrm{z}$ from appearing in the output are found so close to each other on the ranking continuum that they overlap; sometimes $* \square$ outranks $* z$, and sometimes $* \mathrm{z}$ outranks $* \square$. The ranking of these two with respect to the other constraints cannot be determined; in (14) I have placed them at the bottom of the hierarchy for convenience, but in fact they could be placed at the top or in the middle without affecting the analysis. I have separated them with a wavy line to indicate that they overlap in the ranking. The other crucial constraints are IDENT(cor), preventing debuccalization or any other change in place of articulation, $* \mathrm{~V}[\square$ voi] $\mathrm{V}$, prohibiting the most faithful candidate [pre:s[n] from surfacing, and IDENT(voi), which both optimal candidates violate equally and which therefore cannot decide between them. Once again, the absence of debuccalization is crucial, as it shows the high rank of IDENT(cor) in Manx phonology.

\begin{tabular}{|c|c|c|c|c|c|}
\hline /pre:s】n/ & IDENT(cor) & *V[־voi] V & IDENT(voi) & $* \square$ & $*_{\mathrm{z}}$ \\
\hline pre:sవn & & $* !$ & & & \\
\hline ( pre:zDn & & & $*$ & & $*(!)$ \\
\hline ( pre:0Dn & & & $*$ & $*(!)$ & \\
\hline pre:hDn & $* !$ & $*$ & & & \\
\hline
\end{tabular}

The process of PL in Manx is clearly and uncontroversially phonological. Both of its effects, voicing and spirantization in intervocalic position, are crosslinguistically well attested, and above all, the process affects natural classes in a uniform way. The same cannot be said for ML. 


\subsection{An attempt at a phonological analysis of ML}

A derivational analysis of ML could follow the analyses of Ní Chiosáin (1991) and Grijzenhout (1995) for Irish and of Ball \& Müller (1992) and Pyatt (1997) for Welsh in proposing a set of rules effecting the changes seen in (7). Since derivational rules are allowed to be arbitrary and to be free from phonetic grounding or universal markedness considerations, nothing specific need be said about the triggers for such rules. But in an OT analysis one would have to posit something specific in the input that triggers the mutation; the output with the mutation must be shown to be more harmonic than an alternate candidate with the radical form. The most obvious choice for that something specific in the input is a floating autosegment, as proposed by Lieber (1987). Kibre (1995) does just this as a first approximation, but ultimately argues that the analysis is insufficient and that a combination of rules and OT constraints is necessary to analyze the mutations of Welsh. Gnandesikan (1997), whose focus is not on the triggers of the mutations but rather on the representation of the phonology of Irish mutations, also assumes a morpheme consisting of a floating scale value (taking the place of traditional privative or binary features) as the trigger of that mutation. Translating these accounts into an analysis of ML in Manx, one might assume an underspecified morpheme $\mathrm{L}$ that contains at least the feature [+cont] (or maybe some sort of scale value as Gnanadesikan argues for Irish); this morpheme appears in ML environments and coalesces with the initial consonant of the stem to cause the changes shown in (7).

The constraint MORPHREAL requires the distinct realization of a morpheme; it makes the following requirements (Gnanadesikan 1997, 57):

\section{(15) MORPHREAL}

A morpheme must be realized by fulfilling one of the following conditions:

a. the output affixed form contains at least one segment not in the unaffixed form, and that segment(s) is coindexed with a segment(s) in the affix's input;

b. the output affixed form contains a segment which is coindexed with the affix's input and that segment has a scale (or feature) value contained in the affix's input but not in the unaffixed form;

c. the output affixed form contains a segment which is coindexed with the affix's input and that segment has a scale value adjacent to that of the affix's input. That value does not occur in the unaffixed form.

MORPHREAL is violated by the first candidate in (16) because the morpheme / $\mathrm{L} /$ is not present in the output in a way that is distinct from the radical form of [bedn]. The winning candidate coalesces $/ \mathrm{L} /$ and /bedn/ into [vedn].

(16) \begin{tabular}{|r||c|c|}
\hline /Dn L bedn/ & MORPHREAL & IDENT(cont) \\
\hline \hline In bedn & $* !$ & \\
\hline In vedn & & $*$ \\
\hline
\end{tabular}

Alternatively, the trigger might be not an independent morpheme /L/ but instead a floating autosegment at the right edge of the definite article, whose input would then be not $/ \mathrm{Dn} / \mathrm{but}$ $/ \mathrm{GnL} /$. In this case, L would be almost like a segment, except that it has no root node and consists only of the features necessary to trigger ML (either [+cont], or under Gnanadesikan's theory, a scale value). The constraint ruling out *[[n bedn] would then be not MORPHREAL but rather $\operatorname{MAx}(\mathrm{L})$. 
(17)

\begin{tabular}{|r||c|c|}
\hline$/$ [nL bedn/ & MAX(L) & IDENT(cont) \\
\hline In bedn & $* !$ & \\
\hline In vedn & & $*$ \\
\hline
\end{tabular}

There are a number of arguments against both of these analyses. In $\S 3$ I discuss some of the arguments against such an analysis for Celtic mutations in general; one argument that is specific to Manx is the fact that we are confronted with a ranking paradox. Above in (13) we saw that IDENT(cor) crucially outranks $* \square$ in PL, but since d becomes $\square$ under ML, the opposite ranking must hold here, as shown in (18).

\begin{tabular}{|r||c|c|c|c|}
\hline$/ \mathrm{d} \square \mathrm{L}_{1} \mathrm{~d}_{2} \mathrm{ulis} \square$ & MORPHREAL & $* \square$ & IDENT(cor) & IDENT(cont) \\
\hline \hline $\mathrm{d} \square \mathrm{d}_{1,2} \mathrm{ulis} \square$ & $* !$ & & & \\
\hline $\mathrm{d} \square \mathrm{\square}_{1,2} \mathrm{u}$ lis $\square$ & & $* !$ & & $*$ \\
\hline $\mathrm{d} \square \mathrm{\square}_{1,2} \mathrm{ulis} \square$ & & & $*$ & $*$ \\
\hline
\end{tabular}

Because the PL facts show that Manx does tolerate $\mathrm{C}$ in the output, there is no good reason why a process that changes noncoronal stops into the corresponding fricatives should remove the coronality of $d$. As for $t$, we do not expect them to have the same output under ML (which respects input voicing specifications) as under PL (whose outputs are always voiced), but nevertheless debuccalization of $t$ to $h$ appears phonologically unmotivated. According to Broderick (1984-86, 3: 5), Manx has surface 7 as an optional allophone of $/ \mathrm{t} / \mathrm{after} / \mathrm{s} / \mathrm{in}$

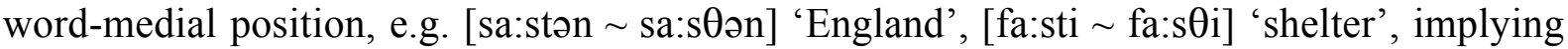
that there is no blanket prohibition on output $\mathrm{C}$ in Manx. Why then should $\mathrm{C}$ not be the ML correspondent of $\mathrm{t}$ ? Arguments that ML (but not PL) must be "structure-preserving" (i.e. that it cannot produce sounds that are outside the phonemic inventory of Manx) fail because ML does produce $\mathrm{C}$, which is not a phoneme of Manx.

Unlike the other Celtic languages, Manx has a phonological lenition whose effects, as we have seen in this section, have serious repercussions on any phonological analysis of ML. A ranking paradox arises if we try to generate both PL and ML from the same constraint ranking. Only PL is clearly an interaction of markedness and faithfulness. An OT-phonological analysis of ML must allow faithfulness to be violated without an improvement in markedness, a situation that is not supposed to occur if the strongest version of the OT phonology hypothesis is correct. As we see in the next section, there are equally strong reasons from other Celtic languages to believe that the mutations are not phonological processes.

\section{Why the mutations cannot be phonological at all}

Not only are the environments of the mutations nonphonological, the mutation processes themselves cannot convincingly be analyzed as phonological either. First of all, there is no feature or bundle of features that can effect the wide variety of alternations found within a single mutation. Secondly, in the case of mutations triggered by syntactic position, a phonological account depends on the assumption of a segmentally empty morpheme containing the mutation-triggering features, but in such cases there is almost never independent evidence for the existence of such a morpheme. Rather, morphemes must be posited for no other reason than to "explain" the occurrence of a mutation. Thirdly, mutations are sometimes triggered by 
proclitics that are not adjacent to the word undergoing mutation. Finally, mutations are subject to a variety of lexical exceptions and irregularities that are inconsistent with a phonological analysis.

\subsection{Features triggering mutations}

The first major problem a phonological account of the mutations encounters is the wide variety of changes triggered. Irish Lenition, for example, turns oral stops and $m$ (but not $n$ ) into fricatives, debuccalizes coronal obstruents, "laxes" tense coronal sonorants, and deletes $\mathrm{f}$. What feature(s) could cause these changes? [+continuant] alone will trigger only the spirantization, not the debuccalization, sonorant laxing ${ }^{9}$, or f-deletion. [ $\square$ coronal] could conceivably account for the debuccalization of coronals, but the majority of researchers on distinctive features (Sagey 1986, McCarthy 1988, Hume 1992, Clements \& Hume 1995) agree that [coronal] is actually a privative feature with no minus value. If a case can be made that what distinguishes $\left[\mathrm{L}, \mathrm{L}, \mathrm{N}, \mathrm{N} \square^{10}\right.$ from $\left.[1,1] \mathrm{n}, \mathrm{n}\right]$ is the feature [tense] (as assumed, for example, by Ó Siadhail 1989: 92 ff.), then [पtense] could account for the sonorant laxing, but not the other cases. And it is difficult to conceive of any feature that could be added to $\mathrm{f}$ to induce deletion. Unlike truly phonological processes (PL in Manx, for example), the mutations do not target natural classes of sounds or have uniform effects. Neither do they improve markedness, as the strong OT phonology hypothesis predicts phonological processes should when faithfulness is violated.

In the next sections we will examine the various environments of the mutations and show that the predominant assumption about their triggers, namely that floating autosegments coalesce with initial consonants to cause the mutations, cannot be supported. In most cases there is no independent evidence for the existence of the morphemes these floating autosegments are supposed to represent. Furthermore, there are so many irregularities and exceptions to mutations, both on the part of the triggers and on the part of the targets, that an analysis operating within the strict bounds of phonological theory simply falls apart.

\subsection{Syntactically triggered mutations}

Analyses that assume a segmentally empty morpheme to trigger mutations are plagued by the inability to provide independent evidence for the morpheme proposed. This is most noticeably the case in mutations that are triggered by syntactic position rather than by an overt proclitic. As shown in (19), attributive adjectives in Irish are lenited when they modify a feminine singular noun, as in (19a). Adjectives are not lenited, however, when they modify a masculine singular noun, as in (19b). When adjectives modify a plural noun they are lenited only if the noun ends in a palatalized consonant; if more than one adjective is present only the first is lenited, see (19c). If the plural noun does not end in a palatalized consonant the adjective is not lenited, see (19d).

(19) Irish Lenition of attributive adjectives
a. bean mhór dhubh
woman big dark
'a big dark woman'
(mór, dubh)

\footnotetext{
9 Lenited $[1,1] \mathrm{n}, \mathrm{n} \square$ are still $[\square$ continuant], showing that [+continuant] cannot be argued to be a consistent feature of Lenition.

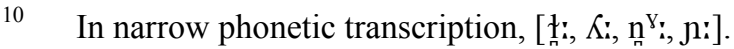




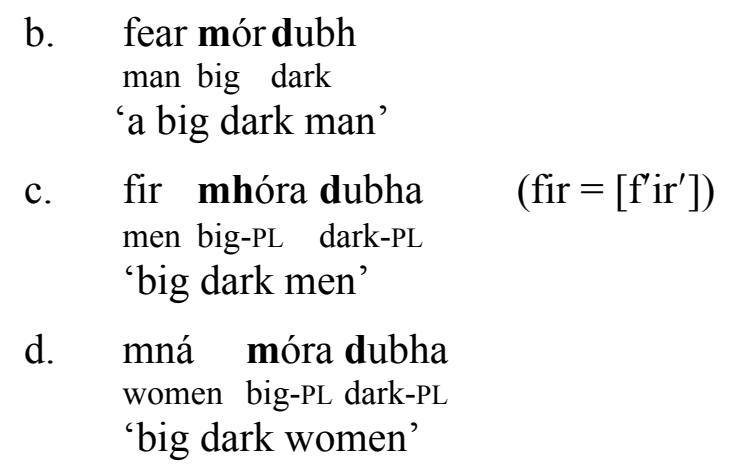

It is virtually impossible to conceive of a functional element that could be found in the Lenition environments of (19): what morpheme could be found in these syntactic positions? Even if an argument could be made for the existence of such an element, there is no independent evidence for it: the only evidence for the presence of a morpheme is the Lenition the morpheme has been invented to explain, and the analysis is nothing more than begging the question.

The exact same point can be made for the syntactically triggered Lenition in (20). Definite noun phrases in a genitival function undergo Lenition, regardless of whether they are morphologically in the genitive case ((20a)) or not ((20b)).

(20) Irish Lenition of genitival definite noun phrases
a. muintir Sheáin
family S.-GEN
'Seán's family'
(Seáin)
b. mac[fhear an tí]
'the son of the man of the house; the landlord's son'

Once again, even if we were to argue that there is, for example, a segmentless preposition meaning 'of' in these phrases, there is no independent evidence for it, and we have merely invented an ad-hoc construct that explains nothing.

One of the most contentious mutations among Celtic syntacticians is the Welsh SM commonly called "direct object mutation" illustrated in (21). As shown in (21a), the direct object of a finite verb undergoes SM, while as shown in (21b), there is no SM when the verb is nonfinite (e.g. the verbal noun, abbreviated VN). (Examples from the handout of Tallerman 2003.)

(21) Welsh direct object mutation

a. Prynodd y ddynes feic.
bought the woman bike
'The woman bought a bike.'

b. Roedd y ddynes yn prynu beic.
was the woman PROG buy-vN bike

'The woman was buying a bike.'

There are two major schools of thought on this problem. Some researchers (e.g. Zwicky 1984, Roberts 1997) have argued that the SM in (21a) is a manifestation of accusative Case (which 
is otherwise not morphologically indicated in Welsh, not even on pronouns as in English), the idea being that the object of a nonfinite verb is not in the accusative. Roberts (in press) argues that the trigger is a floating-autosegment morpheme located in $v$ (a functional head preceding $\mathrm{VP}$, in the Spec position of which the direct object is found).

Other researchers (e.g. Borsley \& Tallerman 1996, Tallerman 1998, 1999, 2003, Borsley 1997, 1999) have pointed out a number of problems with the Case-based analysis and have argued that the SM is triggered instead by a preceding c-commanding phrase or phrasal sister. This suggestion is known as the XP Trigger Hypothesis (XPTH). The evidence for the XPTH comes from the following facts: the direct object of a nonfinite verb is lenited when it is separated from the verb by another phrase like a prepositional phrase or adverbial phrase. Compare the absence of SM in (21b) with its presence in (22).

(22) Direct object of verbal noun lenited after PP or AdvP

Yroedd Prŷs yn rhagweld [pp yn 1721] dranc yr iaith Gymraeg.

was P. PROG foresee-VN in death the Welsh language

'Prŷs foresaw in 1721 the death of the Welsh language.' (tranc)

yn ffaelio [AdvP 'n glir lân] ddyscu 'r gelfyddyd (dyscu)

PROG fail-VN PRED complete learn-VN the art

'completely failing to learn the art'

There are also cases where a noun or verbal noun that cannot be in the accusative is lenited after a phrase in a marked word order, as shown in (23).

(23) SM after a phrase in a marked word order

Mae [pp yn yr ardd] gi.

is in the garden dog

'There's a dog in the garden.'

Mae chwant [pparnafi] fynd adre'. (mynd)

is desire on me go-vN home

'I want to go home.'

Erfyniodd [pparnaf i] fynd gydag ef. (mynd)

begged-3SG on me go-vN with him

'He begged me to go with him.'

The nonfinite verb of an embedded complement clause is lenited after its subject, as shown in (24).

(24) SM of a nonfinite verb after its subject

Mae Aled yn awyddus i Rhys fynd adre'.

is A. PRED eager to R. go-VN home

(mynd)

'Aled is eager for Rhys to go home.'

Wrth i Aled ddod allan, mi aeth Mair i mewn. (dod)

as to A. come-VN out PRT went-3SG M. in

'As Aled came out, Mair went in.'

The subject of a sentence lenites whatever follows it, as shown in (25). This instance also subsumes the SM in (21a). Note in (25b) and (25d) that even the negative particle dim can be lenited, proving that not only nouns are subject to this syntactically triggered SM. 
(25) SM after the subject
a. Gall y dyn ddreifio ' $r$ car.
can the man drive-vN the car
'The man can drive the car.'
b. All y dyn ddim dreifio 'r car.
NEG-can the man NEG drive-VN the car
'The man can't drive the car.'
c. Gwnaeth Aled weld y ffilm.
did-3SG A. see-VN the film
'Aled saw the film.'
d. Gwnaeth Aled ddim gweld y ffilm.
did-3SG A. NEG see-VN the film.
(dreifio)
(dim)
(gweld)
'Aled didn't see the film.'

The conclusion that Tallerman and Borsley come to is that SM is triggered simply by the presence of a preceding XP, not by a functional morpheme like $v$. This conclusion supports the contention of the current paper that mutations are not triggered by silent morphemes consisting solely of floating features.

\subsection{Nonadjacency}

There are a number of cases of mutation triggered by a proclitic that is not adjacent to the word undergoing the mutation. For example In Irish, when a noun is governed both by a possessive pronoun and by dha' 'two', it is the pronoun that determines the mutation. Without a possessive pronoun before, dhá always causes Lenition. In (26a) - (26c), both the pronoun and the numeral independently cause Lenition, so we cannot tell which is triggering Lenition when both occur together. But in (26d) we see that the pronoun triggers the radical form, even when the numeral intervenes. If $d h a$ s were to end in a floating Lenition-triggering autosegment, we have no explanation for why Lenition is blocked here. It is the pronoun that determines the mutation or nonmutation of the noun, even when the pronoun is not adjacent to the noun. This is made even more clear in $(26 \mathrm{e})-(26 \mathrm{~g})$, where the pronoun triggers Eclipsis and the numeral Lenition. Once again, it is the nonadjacent pronoun rather than the adjacent numeral that determines the mutation of the noun.

(26) Possessive pronoun $+d h a ́+$ noun (Irish)

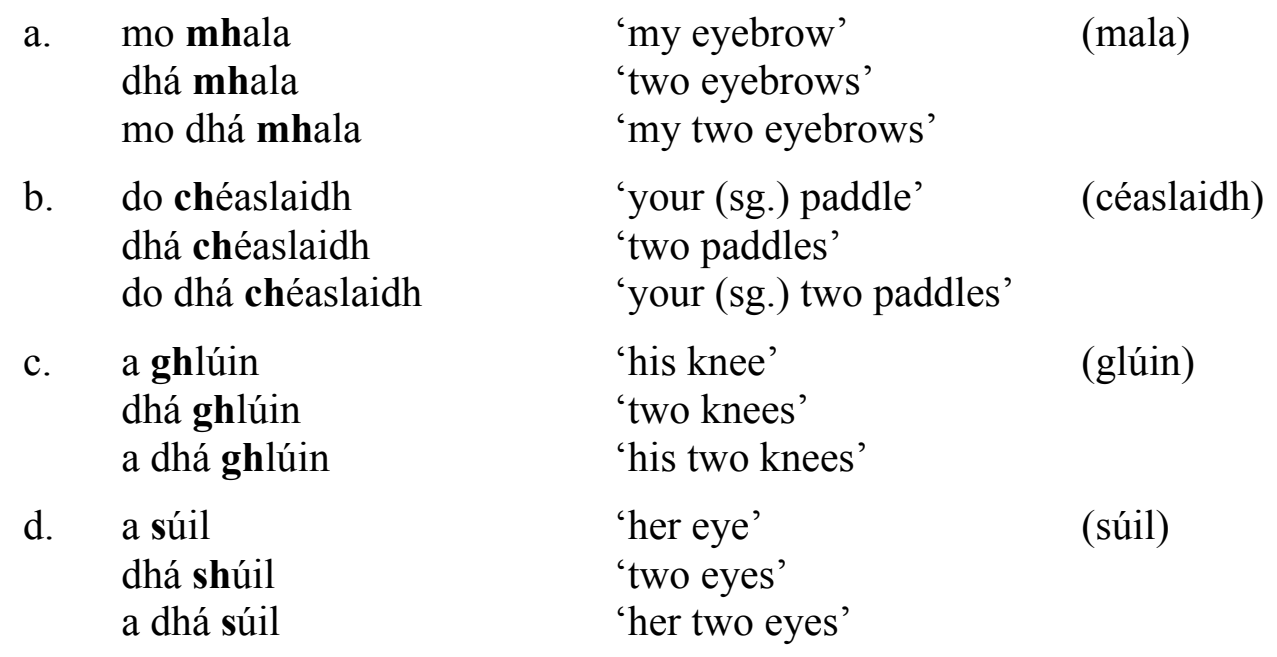


$5 \quad$ cúig cinn $(*$ chinn $)$

6 sé slata $(*$ shlata $)$ 'five ones (things, animals)'

'six yards'

If mutations are triggered by a floating autosegment at the right edge of the triggering proclitic, we cannot explain why Lenition fails to appear when the noun is in the plural. Alternatively, it could be argued that a silent morpheme appears between numerals and singular nouns but not before plural nouns, but firstly such a morpheme is difficult to motivate on methodological grounds (why should a morpheme be expected in such a position?) and secondly there is no independent evidence for a morpheme, which would be invented solely to explain the mutation.

Another example of irregular trigger behavior comes from past tense verbs. Historical tenses (past, past habitual, and conditional) of regular verbs (and many irregular verbs) in Irish are characterized by Lenition, regardless of whether a proclitic is present or not (cf. (29a)). A systematic exception to this generalization is the past tense of the so-called autonomous verb form (which has an impersonal or passive meaning), where the radical is found, again regardless of whether a proclitic is present or not (cf. (29b)). In the case of the personal forms, there is in fact evidence for a triggering proclitic: vowel-initial verbs are supplied with a preverb $d^{\prime}$ in historical tenses when no other preverb is present (cf. (29c)). ${ }^{12}$ Thus a case could be made that there is a preverbal element before historical tense verbs which surfaces as $d$ ' before vowels and as Lenition on consonants. Since $d$ ' is absent before vowel-initial past autonomous forms (cf. (29d.i)), the absence of Lenition in (29b.i) is expected: the triggering particle is absent.

(29) Mutation in the past tense in Irish

a. Lenition in personal forms
i. bhris mé
break-PAST I
'I broke'
ii. níor bhris mé
NEG-HIST break-PAST I
'I did not break'

b. Radical in autonomous forms

i. briseadh an chathaoir

break-PAST-AUT the chair

'The chair got broken'
ii. níor briseadh an chathaoir
NEG-HIST break-PAST-AUT the chair
'The chair did not get broken'

c. $\quad D^{\prime}$ before vowel-initial personal forms in absence of other preverb
i. d' oscail mé
HIST open-PAST I
'I opened'
ii. níor oscail mé
NEG-HIST open-PAST I
'I did not open' 12 In old-fashioned literary style, and to some extent in older varieties of spoken Munster Irish, the full form
do is found also before consonant-initial verbs. 
d. No $d$ ' before vowel-initial autonomous forms

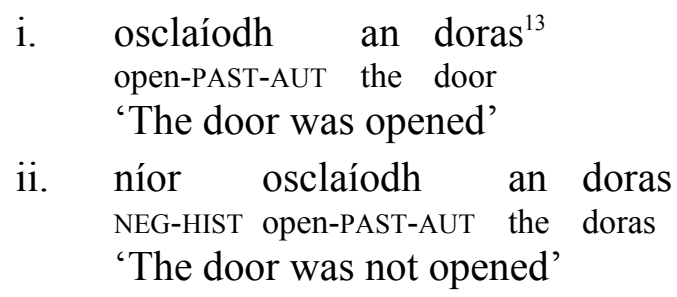

But a problem arises with (29b.ii): the preverb nior triggers Lenition by itself, (29a.ii); it is not followed by the $d^{\prime}$ preverb, (29c.ii). If the mutation is to be represented as a floating autosegment at the right edge of nior, we predict nior to mutate autonomous forms as well, which it does not.

A third example of irregular behavior in a mutation trigger is the negative particle cha of the Ulster (northern) dialect of Irish. This particle triggers Eclipsis of $t, d$, and vowels ${ }^{14}$, leaves $\mathrm{s}$ in the radical (which may be a vacuous application of Eclipsis), but triggers Lenition of noncoronal lenitable consonants, as shown in (30). This phenomenon is known as "mixed mutation." 15

(30) Mixed mutation after cha in Ulster

$\begin{array}{lll}\begin{array}{l}\text { cha dtugann } \\ \text { cha ndéanaim } \\ \text { chan abróchainn }\end{array} & \text { 'does/will not give' } & \text { (tugann) } \\ \text { chan innseochadh sé } & \text { 'I do/will not do', } & \text { (déanaim) } \\ \text { chan ólann tú } & \text { 'you do/will not drink' } & \text { (abróchainn) } \\ \text { cha sílfinn } & \text { 'I would not think' } & \text { (ólann) } \\ \text { cha bhíonn } & \text { 'is not (habitual)/will not be' } & \text { (sílfinn) } \\ \text { cha chreidim } & \text { 'I do not believe' } & \text { (bíonn) } \\ \text { chan fhágaim } & \text { 'I do/will not leave' } & \text { (creidim) }\end{array}$

The Ulster mixed mutation is even more complicated than any of the usual mutations: it voices $t$, nasalizes $d$ and vowels, spirantizes noncoronal stops, and deletes $f$, but does not affect s. It is highly improbable that a single feature or bundle of features, or scale value (Gnanadesikan 1997) can do all of that. And even if one could, why should cha be the only word where this feature (bundle) or scale value appears?

The Irish preposition gan 'without' has a very irregular mutation pattern. In general, it triggers Lenition, as shown in (31a). However, it fails to lenite nouns that are qualified, (31b), or when it functions as the negation in a nonfinite clause, (31c). It does not lenite the coronals $\mathrm{t}, \mathrm{d}, \mathrm{s}$ (which is not surprising since coronals are usually blocked from leniting after other

13 In informal varieties of Irish, hosclaiodh an doras may also be heard (M. Ní Chiosáin, p.c.). Recall from (6) that vowel-initial nouns take a prothetic $h$ after radical-triggering forms of the definite article. This is true also after other radical-triggering vowel-final proclitics like chomh [xo] 'so', go 'to, until', le 'with', etc. Thus the pattern became established that vowel-initial words take prothetic $h$ in environments where consonant-initial words take the radical form.

14 It is an orthographic convention that the prothetic $n$ that vowels acquire under Eclipsis is written at the end of cha rather than the beginning of the following word, hence chan ólann tú rather than cha n-ólann tú for 'you do not drink'.

15 This is the pattern prescribed by Ó Dónaill (1977: s.v. cha), but in texts written in Ulster Irish (searched on the Tobar na Gaedhilge database, Ó Duibhín 2003) the usage is more variable, with Eclipsis found not only on $t$ and $d$ but sometimes on other eclipsable consonants as well. In some texts, $d$ is left in the radical after cha. 
coronals: see Ní Chiosáin1991), nor does it lenite $\mathrm{f}$ (which is surprising as gan is the only leniting proclitic that fails to lenite f), except that it does lenite the word fios 'knowledge', as shown in (31d). It does not lenite proper names, as shown in (31e), although other leniting prepositions do lenite proper names (e.g. ó Mhícheál 'from Mícheál'). ${ }^{16}$

(31) Mutation pattern of gan 'without'

a. Generally triggers Lenition

\begin{tabular}{|c|c|c|}
\hline gan chiall & 'without sense; senseless' & (ciall) \\
\hline gan mhaith & 'without good; useless' & (maith) \\
\hline gan mheabhair & $\begin{array}{l}\text { 'without consciousness; } \\
\text { unconscious' }\end{array}$ & (meabhair) \\
\hline gan bhréag & 'without lie; indisputable' & (bréag) \\
\hline fear gan phósadh & $\begin{array}{l}\text { 'man without marriage; } \\
\text { unmarried man' }\end{array}$ & (pósadh) \\
\hline cailín gan mhúineadh & $\begin{array}{l}\text { 'girl without manners; } \\
\text { unmannerly girl' }\end{array}$ & (múineadh) \\
\hline fan gan chorraí & $\begin{array}{l}\text { 'wait without motion; wait } \\
\text { motionless' }\end{array}$ & (corraí) \\
\hline fágtha gan chompán & 'left without companions' & (compánaigh) \\
\hline
\end{tabular}

b. No Lenition when the noun is qualified

gan bréag ar bith 'without any lie at all; completely indisputable' gan pingin ina phóca 'without a penny in his pocket'

c. No Lenition when functioning as negation in a nonfinite clause

B' fhearr duit gan corraí.

COP-COND better for-you without move-VN

'It would be better for you not to move.'

Abair leis gan pósadh.

say with-him without marry-VN

'Tell him not to marry.'

Mol dó gan pingin a chaitheamh.

advise to-him without penny to spend-vN

'Advise him not to spend a penny.'

d. No Lenition of coronals or $\mathrm{f}$ (except fios 'knowledge')

i. gan teip 'without fail'

ii. gan dabht 'without a doubt; doubtless'

iii. gan sagart 'without a priest'

iv. gan freagra 'without an answer'

v. gan fhios 'without knowledge, unknowing'

e. No Lenition of proper names

Tháinig tú gan Mícheál. 'You came without Mícheál.'

The only failure of Lenition in (31) that can be explained phonologically is that of (31d.i-iii), where coronals fail to lenite after the $n$ of gan. All the other cases where gan does not trigger Lenition are unexplainable if we believe that gan contains a floating Lenition-triggering autosegment at its right edge.

16 This contrasts with Welsh, where proper names generally fail to undergo mutation in any environment. 
The preposition ar 'on' also generally triggers Lenition, as shown in (32a). However, many descriptive PPs using ar, generally translatable with English adjectives, have the radical form of the noun after the preposition ((32b)). Unqualified phrases of location using ar have the radical form $((32 \mathrm{c}))$, but once these same phrases are qualified, ar once again triggers Lenition ((32d)). In complex prepositions (i.e. PPs that function as prepositions, cf. English for the sake of, in place of) ar does not mutate a following noun (32e)). Finally, there are a few adverbial stock phrases in which ar triggers Eclipsis ((32f)). Many of the abovementioned generalizations have exceptions, some of which are listed in the table.

(32) Mutation pattern of $a r$ 'on'

a. Generally lenites

$\begin{array}{lll}\text { ar bhád } & \text { 'on a boat' } & \text { (bád) } \\ \text { ar bhealach } & \text { 'in a way', } & \text { (bealach) } \\ \text { ar bhord } & \text { 'on a table' } & \text { (bord) } \\ \text { ar chaoi } & \text { 'in a way' } & \text { (caoi) } \\ \text { ar chlé } & \text { 'on the left' } & \text { (clé) } \\ \text { ar chor ar bith } & \text { 'at all' } & \text { (cor 'turn') } \\ \text { ar chuntar } & \text { 'on condition' } & \text { (cuntar) } \\ \text { ar dheis } & \text { 'on the right' } & \text { (deis) } \\ \text { ar dhóigh } & \text { 'in a way' } & \text { (dóigh) } \\ \text { ar dhul amach } & \text { 'upon going out' } & \text { (dul) } \\ \text { ar fhaitíos } & \text { 'for fear' } & \text { (faitíos) } \\ \text { ar theacht abhaile dom } & \text { 'upon my coming home' } & \text { (teacht) }\end{array}$

b. Radical in certain descriptive phrases (usually translatable with an adjective)

$\begin{array}{lll}\text { ar bith } & \text { 'any' } & \text { (bith 'world') } \\ \text { ar bogadh } & \text { 'loose' } & \text { (bogadh 'movement') } \\ \text { ar buile } & \text { 'furious' } & \text { (buile 'madness') } \\ \text { ar cois } & \text { 'afoot' } & \text { (cos 'foot') } \\ \text { ar crochadh } & \text { 'hanging' } & \text { (crochadh 'a hanging') } \\ \text { ar díol } & \text { 'for sale' } & \text { (díol 'a sale') } \\ \text { ar dóigh } & \text { 'wonderful' } & \text { (dóigh 'way, manner') } \\ \text { ar doimhne } & \text { 'deep, in depth' } & \text { (doimhne 'depth') } \\ \text { ar fad } & \text { 'long, in length' } & \text { (fad 'length') } \\ \text { ar fáil } & \text { 'available' } & \text { (fáil 'a getting') } \\ \text { ar fiuchadh } & \text { 'boiling' } & \text { (fiuchadh 'a boiling') } \\ \text { ar fónamh } & \text { 'excellent' } & \text { (fónamh 'benefit') } \\ \text { ar forbhás } & \text { 'top-heavy' } & \text { (forbhás 'top-heaviness') } \\ \text { ar gor } & \text { 'brooding (hen)' } & \text { (gor 'heat') } \\ \text { ar maos } & \text { 'saturated' } & \text { (maos 'saturation') } \\ \text { ar meisce } & \text { 'drunk' } & \text { (meisce 'drunkenness') } \\ \text { ar seachrán } & \text { 'astray' } & \text { (seachrán 'a wandering') } \\ \text { ar siúl } & \text { 'going on, in progress' } & \text { (siúl 'walking') } \\ \text { ar tiús } & \text { 'thick, in thickness' } & \text { (tiús 'thickness') } \\ \text { ar triomú } & \text { 'drying' } & \text { (triomú 'a drying') } \\ \text { Exceptions: } & & \\ \text { ar fheabhas } & \text { 'excellent' } & \text { (feabhas 'excellence') } \\ \text { ar shiúl } & \text { 'gone, away' } & \text { (siúl 'walking') }\end{array}$


c. Radical in unqualified phrases of general location

$\begin{array}{ll}\text { ar barr } & \text { 'on top' } \\ \text { ar colba } & \text { 'on the outside' } \\ \text { ar corr } & \text { 'on edge' } \\ \text { ar deireadh } & \text { 'at last' } \\ \text { ar muir } & \text { 'at sea' } \\ \text { ar tír } & \text { 'on land' } \\ \text { ar tosach } & \text { 'in front' }\end{array}$

d. Usually, Lenition when phrases of location are qualified ar bharr an tí 'on the top of the house; on the top story' (barr)

ar cholba na leapa 'on the side of the bed' (colba)

ar chorr an bhoird 'on the edge of the table' (corr)

ar dheireadh an bháid 'on the end (i.e. stern) of the boat'(deireadh)

ar Mhuir Meann 'on the Irish Sea' (muir)

ar thír na hÉireann 'on the land of Ireland' (tír)

ar thosach an tslua 'at the head of the crowd' (tosach)

Exceptions:

ar ball beag 'in a little while' (ball 'a while')

ar béal maidine 'first thing in the morning' (béal 'opening')

ar bord loinge 'on board ship' (bord 'board')

e. Radical in complex prepositions

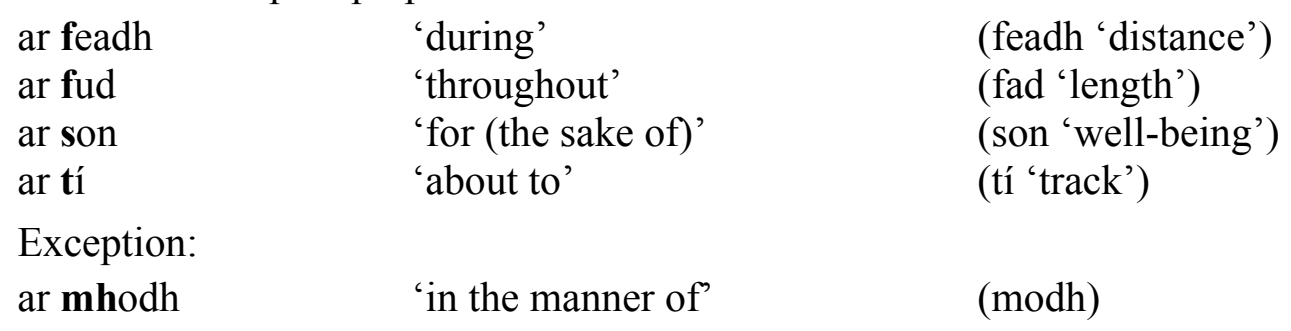

f. Eclipsis in a few adverbial stock phrases

$\begin{array}{lll}\text { ar gcúl } & \text { 'backwards' } & \text { (cúl 'back') } \\ \text { ar ndóigh } & \text { 'of course' } & \text { (dóigh 'certainty') }\end{array}$

Similarly, the preposition thar 'over' generally lenites the initial sound of the noun that follows it, as shown in (33a). It does not mutate certain indefinite, unqualified nouns with a general, often lexicalized, meaning, as shown in (33b), but once these same phrases are qualified, thar once again triggers Lenition, as in (33c).

(33) Mutation after thar 'over'

a. Lenition in most cases

Ní fiú thar phingin é.

'It's not worth more than a penny.' (pingin)

Níor fhan sé thar bhliain ann.

'He didn't stay more than a year there.' (bliain)

Ní aithneodh sé cat thar chóiste.

'He couldn't tell a cat from a carriage.' (cóiste)

thar dhuine eile

'rather than anyone else' (duine) 
Ní raibh thar chúigear acu ann.

'There weren't more than five of them there.'

(cúigear)

thar Chorcaigh

'past Cork'

(Corcaigh)

Níl sé thar mholadh beirte.

'It leaves much to be desired (lit. It's not beyond the judgment of two people).'

(moladh)

b. Radical of indefinite, unqualified nouns

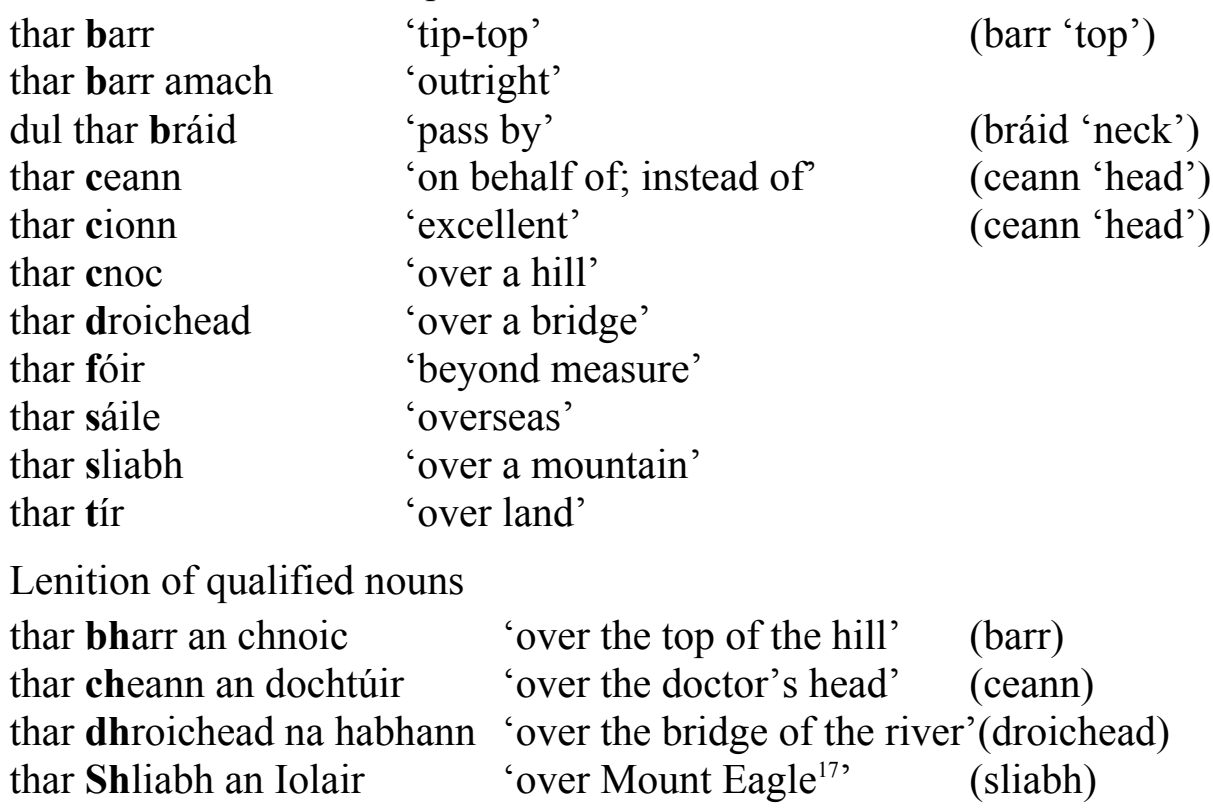

The peculiar mutation behavior of ar and thar is a strong argument against a phonological trigger analysis. If mutations are triggered by floating autosegments at the right edge of the triggering proclitic, we cannot explain why Lenition fails to appear in cases like (32b), (32c), (32e), and (33b). Alternatively, it could be argued that a silent Lenition-triggering morpheme appears between these two prepositions and qualified nouns but not before unqualified nouns, but such a morpheme is particularly difficult to motivate in light of the mutation behavior of gan, where the behavior of qualified and unqualified nouns is exactly the opposite, see (31a) and (31b).

Irregular triggers in Welsh. Mixed mutation similar to that seen above in (30) for Ulster Irish is found also in Welsh, namely after the particles $n i$ 'not', $n a$ 'not (relative)', and oni 'not (interrogative); if not'. As shown in (34), these particles trigger AM of voiceless stops and SM of voiced stops, voiceless liquids, and $\mathrm{m}^{18}$

(34) Mixed mutation after $n i, n a$, and oni in Welsh

$\begin{array}{lll}\text { ni phlesiai } & \text { 'did not please' } & \text { (plesiai) } \\ \text { ni thâl } & \text { 'does not pay' } & \text { (tâl) } \\ \text { ni chymerodd } & \text { 'did not take' } & \text { (cymerodd) } \\ \text { oni chlywodd } & \text { 'has (he) not heard?' } & \text { (clywodd) } \\ \text { ni feiddiai } & \text { 'did not dare' } & \text { (beiddiai) } \\ \text { pam na ddylai } & \text { 'why shouldn't' } & \text { (dylai) }\end{array}$

A mountain on the Dingle Peninsula, County Kerry.

18 In the spoken language, the particle $n i$ itself is often omitted but its mutation effects remain. In some dialects, AM is moribund and usually replaced by SM. 


$\begin{array}{lll}\text { y pethau na welir } & \text { 'the things that are not seen' } & \text { (gwelir) } \\ \text { oni lwydda } & \text { 'unless (he) succeeds' } & \text { (llwydda) } \\ \text { ni raid } & \text { 'there is no need' } & \text { (rhaid) } \\ \text { na feddylier } & \text { 'do not think' } & \text { (meddylier) }\end{array}$

Since this mixed mutation turns all stops ${ }^{19}$ into fricatives (unlike regular SM which turns only voiced stops into fricatives) it might be tempting to assume here that $n i$, na and oni carry a floating [+cont] feature at their right edge, different from the usual trigger of SM. But this analysis still does not capture the voicing of $\mathrm{C}$ and $\mathrm{rlto} 1$ and $\mathrm{r}$, nor is it particularly satisfying in light of the fact that $n i, n a$, and oni are the only particles that behave this way.

There are a number of environments in Welsh where obstruents and $\mathrm{m}$ are lenited, but $\square$ and r rremain in the radical. These environments include: feminine nouns after the definite article and after un 'one' see (35a), adjectives after cyn 'as', mor 'so', and pur 'quite', see (35b), and nouns and adjectives after the predicative particle $y n$, see (35c).

(35) SM of consonants except Ц r $\mathrm{Bn}$ Welsh

a. Feminine nouns after the definite article and after $u n$ 'one'

$\begin{array}{lll}\text { y gyllell } & \text { 'the knife' } & \text { (cyllell) } \\ \text { y fam } & \text { 'the mother' } & \text { (mam) } \\ \text { y llysywen } & \text { 'the eel' } & \\ \text { y rhaff } & \text { 'the rope' } & \text { (merch) } \\ \text { un ferch } & \text { 'one girl' } & \text { (cath) } \\ \text { un gath } & \text { 'one cat' } & \\ \text { un llaw } & \text { 'one hand' } & \\ \text { un rhwyd } & \text { 'one net' }\end{array}$

b. Adjectives after cyn 'as', mor 'so' and pur 'quite'

\begin{tabular}{lll}
$\begin{array}{l}\text { cyn wynned â } \\
\text { cyn gryfed â }\end{array}$ & $\begin{array}{l}\text { 'as white as' } \\
\text { cyn llawned â } \\
\text { cyn rhwydded â }\end{array}$ & $\begin{array}{l}\text { 'as strong as' } \\
\text { (cryfed) }\end{array}$ \\
$\begin{array}{l}\text { mor deg } \\
\text { mor osgeidlid as' }\end{array}$ & \\
mor llydan & 'so fair' & (teg) \\
mor rhwydd & 'so graceful' & (gosgeiddig) \\
pur ddieithr & 'so broad' & \\
pur llwyddiannus & 'so easy' & \\
pur rhydlyd & 'quite strange' & (dieithr) \\
\hline 'quite successful' &
\end{tabular}

c. Adjectives and nouns after the predicative particle $y n$

$\begin{array}{lll}\text { yn ddyn } & \text { 'a man' (pred.) } & \text { (dyn) } \\ \text { yn wag } & \text { 'empty' (pred.) } & \text { (gwag) } \\ \text { yn rhaid } & \text { 'necessary' (pred.) } & \\ \text { yn llygaid } & \text { 'eyes' (pred.) }\end{array}$

The failure to lenite in (35a) cannot be attributed to any underlying phonological property of the definite article and $u n$ 'one' (such as a specific feature or feature bundle that fails to lenite

19 Except g, which is deleted as usual under SM in Welsh. 
$\square$ and $\mathrm{rl}$, because the voiceless liquids are in fact lenited in feminine adjectives after these determiners. Examples are shown in (36).

(36) $\mathrm{SM}$ of $\mathrm{C}$ and $\mathrm{r}$ [n feminine adjectives after the definite article and $u n$

$\begin{array}{lll}\text { y lwyd wawr } & \text { 'the gray dawn' } & \text { (llwyd) } \\ \text { y lonnaf } & \text { 'the happiest (woman)' } & \text { (llonnaf) } \\ \text { un ryfedd yw hi } & \text { 'she is a strange one' } & \text { (rhyfedd) }\end{array}$

As for $(35 b)-(35 c)$, although there is no direct evidence like (36) showing that the failure to lenite $\square$ and rlcannot be attributed to the phonology of the triggering proclitic, it seems a priori unlikely since that explanation cannot be right for (35a).

Another case of lexeme-specific mutation is found with the Welsh words blwydd 'years old', blynedd 'years', and diwrnod 'days'. These words undergo NM (optionally in the case of diwrnod) after the numbers pum ' 5 ', saith '7', wyth '8', naw '9', deng '10', pymtheng '15', ugain '20', and can '100'. Some examples are shown in (37a). However, these are the only words mutated after these numbers. As shown in (37b), other words use the radical form in this context.

(37) Mutation of blwydd, blynedd, and diwrnod after certain numbers

\begin{tabular}{|c|c|c|c|}
\hline a. 5 & pum mlwydd & 'five years old' & (blwydd) \\
\hline 7 & saith mlynedd & ‘seven years’ & (blynedd) \\
\hline 8 & wyth niwrnod/diwrnod & 'eight days' & (diwrnod) \\
\hline 9 & naw mlwydd & 'nine years old' & (blwydd) \\
\hline 10 & deng mlynedd & 'ten years' & (blynedd) \\
\hline 5 & pum dyn & 'five men' & \\
\hline 7 & saith cath & 'five cats' & \\
\hline 8 & wyth blaidd & 'eight wolves' & \\
\hline 9 & naw bachgen & 'nine boys' & \\
\hline 10 & deng merch & 'ten girls' & \\
\hline
\end{tabular}

Once again, a phonological analysis involving a floating autosegment at the right edge of the trigger is highly implausible, since such a floating element would have to marked as applying to only three lexical items and to no other words.

Irregular targets in Irish. Forms of the Irish verb 'to say' that begin with $d$ - (e.g. deir (present) and duirt (past)) do not undergo Lenition in the standard language after particles that otherwise cause Lenition, such as the negative particle $n i$ and the direct relative particle $a$ : $n i$ deirim 'I do not say' (*ní dheirim), nuair a dúirt tú 'when you said' (*nuair a dhúirt tú). If leniting proclitics like $n i$ end in a floating autosegment, it is difficult to explain why those features fail to trigger Lenition in this word. Other words that regularly resist Lenition are méid 'amount', Dé '-day' (in names of days), and t(o)igh 'at the house of' (Ó Siadhail 1989: 114).

In Old Irish, the normal Lenition of $\mathrm{s}$ was $\mathrm{h}$, as it is in Modern Irish. But the word siur 'sister' exceptionally became fiur rather than *[hiur] under Lenition..$^{20}$ If a feature or feature bundle is supposed to be responsible for debuccalization, why is there no debuccalization in

20 There are a few other words that show s $\square$ f Lenition, but only word-internally, e.g. seiser 'group of six people' vs. mór-feiser 'group of seven people' (lit. 'large group of six people') and sephainn [s®f $\square \mathrm{N} \square$ 'played' (reduplicated preterite of seinn-). 
this word? And when debuccalization fails, why should the coronal fricative become a labial fricative?

The Irish irregular verb faigh 'get, find' is irregular not only in its inflection but in its mutation behavior as well. Whereas the negative particle ni causes Lenition of every other verb in the language that begins with a lenitable consonant, it causes Eclipsis of faigh, as in the examples in (38).

$$
\begin{aligned}
& \text { Eclipsis of faigh after } n i \\
& \text { ní bhfaighidh sé } \\
& \text { ní bhfuair sé }
\end{aligned}
$$

'he will not get/find'

'he did not get/find'

Other leniting particles, such as the direct relative particle $a$, do lenite faigh as expected, e.g. nuair a fhaigheann siad 'when they get/find'. The behavior of faigh after $n i$ is unexplainable under a phonological analysis of mutation: if $n i$ ends with a Lenition-triggering floating autosegment, or if it is always followed by a silent Lenition-triggering morpheme, why should the Lenition-triggering element switch to an Eclipsis-triggering element before the forms of the verb faigh?

In English loanwords, Lenition applies only if it does not cause debuccalization or deletion; in other words, Lenition does not apply to English loanwords that begin with t, d, s, or $\mathrm{f}^{21}$ The examples in (39) are taken from de Bhaldraithe (1953/1977: $257 \mathrm{f}$.).

(39) Lenition of English words only without debuccalization/deletion

$\begin{array}{ll}\text { a Mhary } & \text { 'Mary!' (vocative) } \\ \text { a Bhridgy } & \text { 'Bridgy!' (vocative) } \\ \text { a Mhike } & \text { 'Mike! (vocative) } \\ \text { faoi Dan } & \text { 'about Dan' } \\ \text { droch-tae } & \text { 'bad tea' } \\ \text { tigh Dick } & \text { 'at Dick's house' } \\ \text { déanta de twine } & \text { 'made of twine' } \\ \text { aon fag } & \text { 'any fag (cigarette)' } \\ \text { Seán Frank } & \text { 'Seán (son) of Frank' } \\ \text { a Fanny } & \text { 'Fanny!' (vocative) } \\ \text { a Sally } & \text { 'Sally!' (vocative) } \\ \text { a Sarah } & \text { 'Sarah!' (vocative) }\end{array}$

If Lenition were an automatic phonological process, we would expect it to apply to English words used in Irish as regularly as it applies to native Irish words. A case could be made within a phonological analysis that the reason English t, d, s, f fail to lenite is recoverability, which could be expressed in OT terms as high-ranking faithfulness to place of articulation. Such an argument would require the assumption that faithfulness constraints on foreign words are higher ranked than faithfulness constraints on native words, an argument that has been made in slightly different forms by Davidson \& Noyer (1997), Itô \& Mester (1999), and Féry (2003). If other evidence were stronger that Lenition is truly a phonological process, then an analysis based on different rankings of faithfulness constraints in loanwords and native words could be made here. But, as I have been showing throughout this paper, phonological analyses

21 Irish speakers generally use a dental articulation for velarized $\mathrm{t}, \mathrm{d}$ in Irish words and an alveolar articulation for $\mathrm{t}, \mathrm{d}$ in English words. It is sometimes claimed that this is the reason English $\mathrm{t}, \mathrm{d}$ fail to lenite, namely because their place of articulation is different. However, in some Munster dialects, palatalized t, $d$ are alveolar also in Irish words (Ó Cuív 1944: 35 f.; Holmer 1962: 34 f.; Ó Sé 2000: 13 f.), and Irish words do undergo Lenition. 
of the mutations are very problematic, and the data in (39), rather than calling for an analysis within a phonological treatment, are instead additional evidence against the mutations being phonological processes at all. As a functional explanation, the intuition that foreign words resist Lenition if the phonological changes are "too extreme" is strong; but since the mutations in general resist a formal phonological analysis, we unfortunately cannot convert that functional intuition into a formal statement.

Irregular targets in Welsh. As in Irish, English words in Welsh resist mutation if the effect is deletion (i.e. if they begin with g), as shown in (40a). This restriction applies to some monosyllabic native Welsh words beginning with $g$ as well. Foreign place names usually do not get mutated (although there is some variation in this respect) regardless of their initial consonant, as shown in (40b), although Welsh place names (including the Welsh names of places outsides Wales) do get lenited: $i$ Fanceinion 'to Manchester' (Manceinion), i Fryste 'to Bristol' (Bryste). Personal names usually resist mutation whether they are of Welsh or foreign origin $((40 \mathrm{c}))$, although in formal texts they can be mutated. In the literary language at least, the adjective braf 'fine' resists SM as well.

(40) Words resisting SM in Welsh

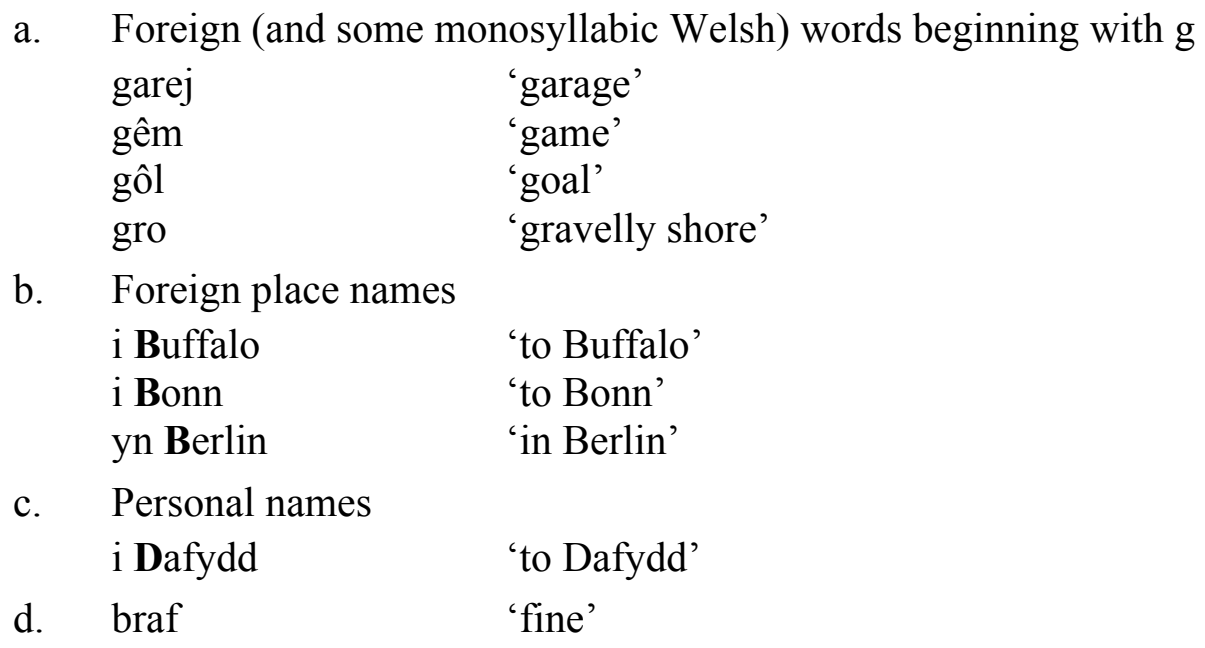

As with the foreign words that resist Lenition in Irish, the Welsh forms in (40) could conceivably be analyzed as belonging to a stratum of the Welsh lexicon to which faithfulness applies more stringently than to native words, if a phonological analysis of mutations were otherwise plausible. But as has been shown throughout this paper, such a phonological analysis is not plausible, and the functional intuition that foreign words resist alteration more than native words do must remain unformalized.

In this section we have seen several ways in which the Celtic mutations fail to exhibit behavior typical of phonological processes: they do not target natural classes of features, have uniform, predictable effects, or reduce phonological markedness in any obvious way. Rather, they are idiosyncratic and arbitrary, both in their environments and in their effects. For these reasons it is preferable to view the mutations not as phonological processes but as morphological effects.

\section{$4 \quad$ Mutations as morphological effects}

In the past section we saw a number of reasons why the most nearly plausible phonological analysis of the mutations, namely that they are triggered by floating autosegments, cannot be 
accurate. In this section I will outline a preferable analysis, according to which the mutated forms of words are listed in the lexicon alongside the radical forms. The grammar then picks the correct allomorph for any given environment. Thus, in spite of the phonological appearance of the mutations, they are in fact entirely outside the phonology; their phonological element can be explained only historically, not synchronically. The mutations are properties of the lexicon, which consists not of roots and affixes, but rather of whole words listed in all their actual surface forms and connected to each other through their shared properties, a view of the lexicon supported by Bybee (1985, 2001), Singh (1987, 1996), Bochner (1993), Ford \& Singh (1996), and Ford et al. (1997).

\subsection{Views of lexical organization}

Probably the most widespread view of the lexicon in generative phonology today is the Itemand-Arrangement (IA) view (Hockett 1958; see also Spencer 1998 for discussion), according to which roots and affixes are listed in the lexicon under unique underlying representations (URs). These roots and affixes may be joined together and then phonological rules (in derivational phonology) or constraints (in constraint-based phonology like OT) apply to generate the surface form. According to the IA view, the alternation seen, for example, in Irish bróg [bro:g] 'shoe' bhróg [vro:g] 'shoe (lenited) mbróg [mro:g] 'shoe (eclipsed)' is to be analyzed thus: the Irish lexicon includes a UR /bro:g/ and a variety of Lenition- and Eclipsis-triggering morphemes, some of which may consist entirely of a floating autosegment, others of which may include a floating autosegment at their right edge. When a mutationtriggering morpheme comes into contact with a potential host word, like /bro:g/, phonological processes (rules, constraint interactions, etc.) apply in such a way as to result in the surface form [vro:g] in Lenition environments and the surface form [mro:g] in Eclipsis environments. If neither process applies then the surface form is radical [bro:g].

In contrast with the IA view, the Item-and-Process (IP) view considers affixal morphemes to be processes that apply to roots in ways that are not always linearly concatenative. An IP view of the Celtic mutations would treat them as processes in themselves that manifest certain morphological properties; there is no assumption of floating autosegments triggering the mutations. Adopting this view alleviates many of the problems discussed above associated with a phonological analysis, but it still assumes that mutated forms can be derived from radical forms. Given the wide variety of phonological changes that a single mutation can cause (e.g. spirantization, debuccalization, deletion, and "laxing" in the case of Irish Lenition) as well as the numerous exceptions and irregularities discussed in $\S 3.4$ above, even the IP view falls short of a satisfying analysis. Moreover, while the IP view of morphology accounts nicely for nonconcatenative morphology like English man-men or write-wrote, holding that the properties "plural" or "past" are manifested by a vowel alternation instead of a segment, extending that analysis to pairs like Irish bróg-bhróg is difficult since the latter is not a manifestation of a single morphological property.

The word-based view endorsed here contrasts with both the IA and the IP views of morphology. It holds that lexical items are listed in the lexicon under all of the forms in which they may surface. Thus affixation, for example, is not a process separate from the lexicon: morphologically complex forms like walks, walked, walking are not derived from walk $+s$, walk+ed, walk+ing etc., but instead are listed whole in the lexicon. Similarly, mutated forms like bhróg and mbróg are not derived from bróg in any way, but are listed alongside it in the Irish lexicon. The job of the grammar is then not to change bróg into bhróg or mbróg but rather to determine which form is used where. 


\subsection{Mutation selection parallel to case selection}

The situation, I suggest, is parallel to that of case selection in languages like Latin, Russian, and German. Consider, for example, the dative case in German. As illustrated in (41), the German dative is used with indirect objects (41a), with the complements of certain verbs and adjectives (41b) - (41c), and with prepositions indicating non-goal-oriented location (41d). In most instances the dative case of a full NP is marked morphologically on the determiner, not the noun itself. Examples are from Helbig \& Buscha (1991).

(41) Dative case in German

a. Indirect objects

Der Dozent traut dem Studenten die Arbeit zu.

the instructor believes-capable the $e_{D A T}$ student the $e_{A C C}$ work PRT

'The instructor believes the student capable of the work.'

Erbietet dem Freund eine Zigarette an.

he offers the $e_{\mathrm{DAT}}$ friend $\mathrm{a}_{\mathrm{ACC}}$ cigarette PRT

'He offers the friend a cigarette.'

b. Complements of certain verbs

Er begegnet dem Freund.

he meets the $\mathrm{DAT}_{\mathrm{DA}}$ friend

'He meets the friend.'

Sie hilft dem Freund.

she helps the DAT $_{\text {friend }}$

'She helps the friend.'

c. Complements of certain adjectives

Der Schüler ist seinem Vater ähnlich.

the $\mathrm{NOM}_{\text {Nom }}$ schoolboy is his $_{\mathrm{DAT}}$ father similar

'The schoolboy is similar to his father.'

Er ist dem Direktor bekannt.

he is the DAT $_{\text {director known }}$

'He is known to the director.'

d. Prepositions indicating non-goal-oriented location

Das Heft liegt im Schrank.

the $_{\text {NOM }}$ booklet lies in-the DAT $_{\text {aT }}$ cupboard

'The booklet is (lying) in the cupboard.'

Der Schrank steht an der Wand.

the $_{\text {NOM }}$ cupboard stands against the wall

'The cupboard is (standing) against the wall.'

Das Kind läuft auf der Straße.

the $_{\text {NoM }}$ child runs on the $\mathrm{DAT}_{\mathrm{T}}$ street

'The child is running on the street.' (i.e. running around there)

With (41d) may be contrasted the forms in (42), where we see that the object of a preposition indicating goal-oriented motion is in the accusative.

(42) Accusative after prepositions indicating goal-oriented motion

Er legt das Heft in den Schrank.

he puts the ${ }_{A C C}$ booklet in the $\mathrm{ACC}_{\mathrm{AC}}$ cupboard

'He puts the booklet in the cupboard.' 
Sie schieben den Schrank an die Wand. they push the $\mathrm{AcC}_{\mathrm{AC}}$ cupboard against the $\mathrm{AcC}_{\mathrm{Ac}}$ wall

'They push the cupboard against the wall.'

Das Kind läuft auf die Straße.

the $_{\text {Nom }}$ child runs on the Acc $_{\text {street }}$

'The child is running onto the street.' (i.e. running towards it)

Interestingly, the preposition $z u$ 'to' always governs dative case, even when goal-oriented motion is indicated, as shown in (43).

(43) Wir gehen zum Bahnhof.

we go to-the $\mathrm{DAT}_{\mathrm{T}}$ railroad-station

'We're going to the railroad station.'

Thus, case selection in German can be determined by either syntactic ((41a), (41d), (42)) or lexical ((41b), (41c), (43)) criteria. Mutation selection in Celtic languages, I argue, works the same way. Just as prepositions in German can subcategorize for what case they govern (the one in (43) even overriding syntactic generalizations), so determiners, prepositions, and other proclitics in the Celtic languages can subcategorize for what mutation grade they govern. For example, the feminine singular definite article in Welsh governs the lenited form of a noun (unless it begins with Dor rll all other forms of the definite article govern the radical form. In Irish, possessive pronouns of the first person singular, second person singular, and third person masculine singular govern the lenited form, that of the third person feminine singular governs the radical form, and those of the plural govern the eclipsed form. And just as syntactic position can determine case in German, so can it determine mutation grade in Celtic languages: for example, the first word in an NP following a c-commanding or sister XP in Welsh (assuming the XPTH is correct) appears in the SM form.

Allowing the morphology and the syntax to directly choose mutation grade has a number of advantages over the hypothesis that mutation is triggered by floating autosegments. For one thing, we are not required to posit silent morphemes in environments where there is no independent evidence for them, nor do we have to resort to highly idiosyncratic phonology in order to achieve the alternations attested. When a feminine noun is lenited after the definite article, as are any adjectives modifying that noun, it is because the syntax of feminine NPs requires it, not because feminines end in a floating autosegment. The nonadjacency cases of $\$ 3.3$ are easily explained under this view: in a phrase like ár dhá gcuid 'our two parts', see (26e), ár requires its noun to appear in the eclipsed form, while $d h a$ r requires its noun to appear in the lenited form. We may hypothesize that the requirement of $a r$ takes precedence, perhaps because it is higher in the tree than dhá. At any rate, the fact that the trigger $a r$ is not adjacent to its target mbád is not a problem under this view. The same holds true of the other nonadjacency cases like trí shioc agus shneachta 'through frost and snow' and Cá bhfuil mo fuckin' sheaicéad? 'Where's my fuckin' jacket?', where the mutation trigger still governs its target even without being adjacent to it.

The irregular behavior of mutation triggers discussed in $\$ 3.4$ can be analyzed by finetuning the subcategorization frames of the triggers (e.g. the numbers 3-6 subcategorize for the lenited form of singular nouns but the radical form of plural nouns in Irish; the particles $n i$, $n a$, and oni subcategorize for the AM form of a word in Welsh where it is available, otherwise the SM form, etc.) The irregular behavior of mutation targets can be analyzed by proposing that individual lexical items can have mutation allomorphs that deviate from the usual pattern. For example, the verb 'to say' in Modern Irish has allomorphs marked "lenited" that 
nevertheless begin with $d$ rather than expected $\mathrm{C}$; the noun 'sister' in Old Irish has an allomorph marked "lenited" that begins with f rather than expected h; and so on.

Thus the mutations are like inflections, but orthogonal to them. According to context, the nominative of 'friend' in Irish is cara, chara or gcara, the genitive carad or charad etc. I am not arguing that mutation is a form of Case-marking, as Zwicky (1984) and Roberts (1997, in press) did for Welsh. Instead, I am asserting that mutated forms are listed in the lexicon in a manner parallel to the listing of inflected forms.

\title{
4.3 Defending a nonphonological analysis
}

Ball \& Müller (1992: 123 f.) anticipate the present analysis in a section considering whether Welsh mutations may be outside the phonology. They criticize this idea thus:

\begin{abstract}
While this on the face of things does remove mutations from the phonology, we are left with sets of forms forms for each lexical item that are clearly very similar phonologically. If we resort to suppletion (i.e. implicitly claiming they are all totally unrelated) the resultant analysis would be seen as eccentric to say the least, and as inadequate in that it refused to account for an obvious set of similarities between the forms. If, on the other hand, we attempt to link the forms, we can only do so via a phonological description. It would seem, therefore, that whatever phonological approach we adopt, and wherever the rules are situated, there is no adequate account of mutations that does not involve some kind of phonological formalism.
\end{abstract}

It would indeed be eccentric and inadequate to claim that the mutated and radical forms of words were totally unrelated and to refuse to account for the similarities. However, it is not the case that the relationships and similiarities among the form can be accounted for only phonologically. Generalizations like "nonlenited [ $\square$ cont] $\square$ lenited [+cont]" are still expressible under the present account, but they are not phonological rules. Instead, they are statements of behavior in the Irish lexicon which have the status of tendencies. During the acquisition process, speakers pick up on alternations like $\mathrm{p} \sim \mathrm{f}$ and $\mathrm{k} \sim \mathrm{x}$ in the same morphosyntactic environments and can spread them analogically to new forms without either adding phonological rules or setting up phonological constraint interactions to handle these alternations. Other Lenition statements are made more specifically, as shown in (44). Again, these are not statements of phonological rules or processes of any kind; they are statements of tendencies in the Irish lexicon that speakers deduce from the lenited/nonlenited pairs they learned during acquisition.

(44) Additional Lenition generalizations for Irish

nonlenited [coronal, $\square$ voi] $\square$ lenited h

nonlenited $\mathrm{d} \square$ lenited $\mathrm{C}$

nonlenited $\mathrm{f} \square$ lenited $\varnothing$

nonlenited $\mathrm{m} \square$ lenited $\mathrm{v}$

Idiosyncratic exceptions to these generalizations, such as the blocking of Lenition in deir 'says' and related forms in Irish, must be learned individually, and will tend to regularize. Indeed, some Ulster Irish texts in the Tobar na Gaedhilge database (Ó Duibhín 2003) do have lenited forms like nior dhuiirt 'did not say' for standard nior duiirt. The Old Irish pair siur fiur 'sister (radical-lenited)' with an idiosyncratic $\mathrm{s} \sim \mathrm{f}$ alternation has been regularized in Modern Irish as siúr $\sim$ shiúr with a regular $\mathrm{s} \sim \mathrm{h}$ alternation and in Scots Gaelic as piuthar $\sim$ phiuthar with a regular $\mathrm{p} \sim \mathrm{f}$ alternation.

As for lexical economy, even though speakers may have a listed f-initial allomorph marked "lenited" corresponding to every (or almost every) p-initial allomorph marked 
"radical", their awareness of the generalization means that the f-initial allomorph does not necessarily "cost anything." If only independent ("new") information adds to the complexity of the grammar, as Bochner (1993) has proposed, then for a pair like /pa:r $\mathbb{k} \square$ fa:r[k $\square$ 'field', only /pa:r $\mathbb{k} \square$ and the Lenition generalization are counted; /fa:r[k $\square$ does not add to complexity in spite of being accessible to the speaker as a listed form in the lexicon. The interested reader is referred to Bybee (1988) for a general response to the charge of uneconomicalness in wordbased morphology.

Questions may also arise concerning the predictive power of the present analysis. Since I have removed the mutations from the restrictions of the phonology and put them in the lexicon, where virtually everything is idiosyncratic, some readers may wonder if there are any limits on what kinds of alternations I predict can happen; indeed, it may seem that I am predicting languages where, in the lexicon at least, anything can alternate with anything. To this I respond that morphologized remnants of historical phonological changes are full of very peculiar things cross-linguistically. Consider English velar softening: what originated as a palatalization of velar stops before front vowels in late variety of Vulgar Latin remains as a set of $\mathrm{k} \sim \mathrm{s}$ and $\mathrm{g} \sim$ Talternations that are no longer phonologically predictable (see Green 2002 for discussion). As mentioned at the beginning of the paper, the strongest theory of phonology concerns itself only with the interaction of markedness and faithfulness. To allow phonology to be powerful enough to account for the quirkiest phoneme alternations is to weaken phonological theory to the point of being unfalsifiable. The lexicon, which is by definition arbitrary, is the natural home of idiosyncrasies and language-specific peculiarities; the phonology is not. The only limits on alternations found in the lexicon are imposed by what alternations historical sound change is likely to result in.

\section{Conclusions}

In this paper I have argued that the traditional view of the Celtic mutations as phonological processes that apply in morphosyntactically determined environments is not tenable. The mutations cannot be shown to reflect the interaction of faithfulness with universal markedness principles, in violation of the strong OT-phonology hypothesis that all phonological processes reflect such an interaction. The morphosyntactically triggered Lenition of Manx contrasts sharply with an intervocalic lenition process in the same language, which is palpably phonological in both its environment and its effects. In all the Celtic languages, the morphosyntactically triggered mutation alternations themselves are not expressible in terms of predictable changes of phonological features, nor can the environments of the changes be convincingly attributed to floating autosegments, as has frequently been claimed since Lieber (1987). Furthermore, the large number of irregularities and exceptions among both triggers and targets strongly suggests that the mutations are properties of the lexicon, not the phonology. Instead, the Celtic mutations are encoded directly in the items listed in the lexicons of the languages, resulting in patterns that are discernible to speakers and that can spread analogically to new forms, even though there are no explicit rules or constraint interactions forcing the mutations. The grammar of each language allows proclitics and syntactic positions to determine which mutation grade of a lexical item is grammatical in which environment, in a manner parallel to the selection of Case by prepositions and syntactic positions in languages like German. 


\section{Appendix: Some environments of mutations in Irish and Welsh}

The following list is representative, not exhaustive. Most examples come from Christian Brothers (1960) or Ó Dónaill (1977) for Irish and King (1993) or Thorne (1993) for Welsh.

(1) Mutations of nouns after the definite article (see (3) - (4) in the main text)

(2) Mutations of nouns after possessive pronouns in Irish

\begin{tabular}{|c|c|c|c|c|}
\hline 'my' & Lenition & mo chos & 'my leg' & $(\cos )$ \\
\hline $\begin{array}{l}\text { 'your' } \\
\text { (sg.) }\end{array}$ & Lenition & do bhróg & 'your (sg.) shoe' & (bróg) \\
\hline 'his' & Lenition & & 'his trousers' & \\
\hline \multirow[t]{2}{*}{ 'her' } & \multirow{2}{*}{$\begin{array}{l}\text { Radical (but } \\
h \text { before a } \\
\text { vowel) }\end{array}$} & a gúna & 'her gown' & (gúna) \\
\hline & & a hál & 'her litter' & (ál) \\
\hline 'our' & Eclipsis & ár mbád & 'our boat' & (bád) \\
\hline 'your' (pl.) & Eclipsis & bhur dteach & 'your (pl.) house' & \\
\hline 'their' & Eclipsis & a gcairde & 'their friends' & \\
\hline
\end{tabular}

(3) Mutations of nouns after possessive pronouns in Welsh

\begin{tabular}{|c|c|c|c|c|}
\hline 'my' & NM & fy mhlant & 'my children' & (plant) \\
\hline $\begin{array}{l}\text { 'your' } \\
\text { (sg.) }\end{array}$ & SM & dy dŷ & 'your (sg.) house' & $(t \hat{)})$ \\
\hline 'his' & SM & ei fam & 'his mother' & (mam) \\
\hline 'her' & $\mathrm{AM}$ & ei chi & 'her dog' & (ci) \\
\hline 'our' & Radical & ein bara & 'our bread' & (bara) \\
\hline 'your' (pl.) & Radical & eich dillad & 'your (pl.) clothes' & (dillad \\
\hline 'their' & Radical & eu gardd & 'their garden' & (gardd) \\
\hline
\end{tabular}

(4) Mutations of nouns after prepositions in Irish

\begin{tabular}{|c|c|c|c|c|}
\hline $\mathrm{a}$ & \multirow[t]{9}{*}{ Lenition } & a dhíol & 'to sell' & \multirow{8}{*}{$\begin{array}{l}\text { (díol) } \\
\text { (Sorcha) } \\
\text { (gasúr) } \\
\text { (bord) } \\
\text { (duine) } \\
\text { (béal) } \\
\text { (maidin) } \\
\text { (Béarla) }\end{array}$} \\
\hline de & & de Shorcha & 'from Sorcha' & \\
\hline do & & do ghasúr & 'to a boy' & \\
\hline faoi & & faoi bhord & 'under a table' & \\
\hline mar & & mar dhuine & 'as a person' & \\
\hline ó & & ó bhéal & 'from a mouth' & \\
\hline roimh & & roimh mhaidin & 'before morning' & \\
\hline trí & & trí Bhéarla & 'through English' & \\
\hline um & & um Shamhain & 'in November' & \multirow{8}{*}{$\begin{array}{l}\text { (Samhain) } \\
\text { (Tomás) } \\
\text { (Seán) } \\
\text { (bean) } \\
\text { (baile) } \\
\text { (Tadhg) } \\
\text { (Pádraig) } \\
\text { (féasóg) }\end{array}$} \\
\hline ach & \multirow{7}{*}{$\begin{array}{l}\text { Radical } \\
\text { (vowel-final } \\
\text { ones add } h \text { - } \\
\text { to a follow- } \\
\text { ing vowel) }\end{array}$} & ach Tomás & 'except Tomás' & \\
\hline ag & & ag Seán & 'at Seán' & \\
\hline amhail & & amhail bean & 'like a woman' & \\
\hline as & & as baile & 'out of town' & \\
\hline chuig & & chuig Tadhg & 'to Tadhg' & \\
\hline chun & & chun Pádraig & 'to Pádraig' & \\
\hline dar & & dar féasóg m'athar & $\begin{array}{l}\text { 'by my father's } \\
\text { beard' }\end{array}$ & \\
\hline
\end{tabular}




\begin{tabular}{|c|c|c|c|c|}
\hline \multirow[t]{2}{*}{ go } & & go Sasana & 'to England' & \multirow{5}{*}{$\begin{array}{l}\text { (Sasana) } \\
\text { (Éirinn) } \\
\text { (teacht) } \\
\text { (airgead) } \\
\text { (Síle) }\end{array}$} \\
\hline & & go hÉirinn & 'to Ireland' & \\
\hline \multirow[t]{2}{*}{ le } & & le teacht & 'with an approach' & \\
\hline & & le hairgead & 'with money' & \\
\hline murach & & murach Síle & $\begin{array}{l}\text { 'were it not for } \\
\text { Síle' }\end{array}$ & \\
\hline seachas & & $\begin{array}{l}\text { seachas } \\
\text { geimhreadh }\end{array}$ & 'besides winter' & (geimhreadh) \\
\hline $\mathrm{i}$ & Eclipsis & i mbaile & 'in town' & (baile) \\
\hline ar & \multirow{3}{*}{\multicolumn{3}{|c|}{ See (31) - (33) in the main text }} & \\
\hline gan & & & & \\
\hline thar & & & & \\
\hline
\end{tabular}

(5) Mutations of nouns after prepositions in Welsh

\begin{tabular}{|c|c|c|c|c|}
\hline$\hat{\mathrm{a}}$ & \multirow[t]{3}{*}{$\mathrm{AM}$} & â chyllell & 'with a knife' & \multirow{7}{*}{$\begin{array}{l}\text { (cyllell) } \\
\text { (plant) } \\
\text { (pum) } \\
\text { (mis) } \\
\text { (bwrdd) } \\
\text { (meddyg) } \\
\text { (dylanwad) }\end{array}$} \\
\hline gyda & & gyda phlant & 'with children' & \\
\hline tua & & tua phum pwys & 'about five pounds' & \\
\hline am & \multirow[t]{13}{*}{ SM } & am fis & 'for a month' & \\
\hline ar & & ar fwrdd & 'on a table' & \\
\hline at & & at feddyg & 'to a doctor' & \\
\hline dan & & $\begin{array}{l}\text { dan ddylanwad } \\
\text { ei rieni }\end{array}$ & $\begin{array}{l}\text { 'under the influence of his } \\
\text { parents' }\end{array}$ & \\
\hline dros & & dros bont & 'over a bridge' & \multirow{7}{*}{\begin{tabular}{|l} 
(pont) \\
(ci) \\
(gwydr) \\
(diwedd) \\
(tad) \\
(Bangor) \\
(mis)
\end{tabular}} \\
\hline gan & & gan gi & 'by a dog' & \\
\hline heb & & heb wydr & 'without glass' & \\
\hline hyd & & $\begin{array}{l}\text { hyd ddiwedd } \\
\text { mis Mehefin }\end{array}$ & 'until the end of June' & \\
\hline $\mathrm{i}$ & & i dad Eleri & 'to Eleri's father' & \\
\hline $\mathrm{O}$ & & o Fangor & 'from Bangor' & \\
\hline $\tan$ & & $\begin{array}{l}\tan \text { fis } \\
\text { Tachwedd }\end{array}$ & $\begin{array}{l}\text { 'until the month of } \\
\text { November' }\end{array}$ & \\
\hline trwy & & trwy fenyn & 'through butter' & \multirow{8}{*}{$\begin{array}{l}\text { (menyn) } \\
\text { (desg) } \\
\text { (diwedd) } \\
\text { (plant) } \\
\text { (Caerdydd) } \\
\text { (tŷ) } \\
\text { (cywilydd) } \\
\text { (Cymru) }\end{array}$} \\
\hline wrth & & wrth ddesg & 'by a desk' & \\
\hline cyn & \multirow[t]{6}{*}{ Radical } & $\begin{array}{l}\text { cyn diwedd yr } \\
\text { arganddosfa }\end{array}$ & $\begin{array}{l}\text { 'before the end of the } \\
\text { show' }\end{array}$ & \\
\hline efo & & efo plant & 'with children' & \\
\hline ger & & ger Caerdydd & 'near Cardiff' & \\
\hline mewn & & mewn tŷ & 'in a house' & \\
\hline rhag & & rhag cywilydd & 'for shame' & \\
\hline rhwng & & $\begin{array}{l}\text { rhwng Cymru a } \\
\text { Lloegr }\end{array}$ & $\begin{array}{l}\text { 'between Wales and } \\
\text { England' }\end{array}$ & \\
\hline yn & NM & yn Nhalybont & 'in Talybont' & (Talybont) \\
\hline
\end{tabular}


(6) Mutations of nouns after numbers 2-10 in Irish (noun in singular form) (but see (27) (28) in the main text)

\begin{tabular}{|c|c|c|c|c|}
\hline 2 & Lenition & dhá theach & 'two houses' & (teach) \\
\hline 3 & Lenition & trí bhád & 'three boats' & (bád) \\
\hline 4 & Lenition & ceithre bhó & 'four cows' & (bó) \\
\hline 5 & Lenition & cúig phunt & 'five pounds' & (punt) \\
\hline 6 & Lenition & sé mhí & 'six months' & (mí) \\
\hline 7 & Eclipsis & seacht gcapall & 'seven horses' & (capall) \\
\hline 8 & Eclipsis & ocht n-asal & 'eight donkeys' & (asal) \\
\hline 9 & Eclipsis & naoi geat & 'nine cats' & (cat) \\
\hline 10 & Eclipsis & deich bpeann & 'ten pens' & (peann) \\
\hline
\end{tabular}

(7) Mutations of nouns after numbers 1-10 in Welsh (noun in singular form)

\begin{tabular}{|c|c|c|c|c|}
\hline 1 , masc. & Radical & un ceffyl & 'one horse' & \multirow{2}{*}{$\begin{array}{l}\text { (ceffyl) } \\
\text { (cath) }\end{array}$} \\
\hline 1, fem. & $\begin{array}{l}\text { SM (except } \\
\text { of } l l, r h)\end{array}$ & un gath & 'one cat' & \\
\hline 2 , masc. & SM & dau geffyl & 'two horses' & (ceffyl) \\
\hline 2, fem. & $\mathrm{SM}$ & dwy gath & 'two cats' & (cath) \\
\hline 3, masc. & AM & tri pharsel & 'three parcels' & (parsel) \\
\hline 3, fem. & Radical & tair ceiniog & 'three pence' & (ceiniog) \\
\hline 4, masc. & Radical & pedwar blaidd & 'four wolves' & (blaidd) \\
\hline 4, fem. & Radical & pedair buwch & 'four cows' & (buwch) \\
\hline 5 & Radical & pum dyn & 'five men' & (dyn) \\
\hline 6 & $\mathrm{AM}$ & chwe cheffyl & 'six horses' & (ceffyl) \\
\hline 7 & Radical & saith pryf & 'seven worms' & (pryf) \\
\hline 8 & Radical & wyth troed & 'eight feet' & (troed) \\
\hline 9 & Radical & naw milltir & 'nine miles' & (milltir) \\
\hline 10 & Radical & deg ĝ̂ydd & 'ten geese' & (ĝ̂ydd) \\
\hline
\end{tabular}

(8) Mutations of attributive adjectives after nouns in Irish (e.g. cóir 'just') (cf. (19) in the main text)

\begin{tabular}{|c|c|c|c|}
\hline Masc. nom. sing. & Radical & fear cóir & 'a just man' \\
\hline Masc. gen. sing. & Lenition & fir chóir & 'of a just man' \\
\hline Fem. nom. sing. & Lenition & máthair chóir & 'a just mother' \\
\hline Fem. gen. sing. & Radical & máthar córa & 'of a just mother' \\
\hline $\begin{array}{l}\text { Dat. sing. (after } \\
\text { definite article) }\end{array}$ & \multirow{2}{*}{$\begin{array}{l}\text { Optional Lenition if } \\
\text { the noun is overtly } \\
\text { lenited, otherwise } \\
\text { radical }\end{array}$} & don fhear c(h)óir & 'to the just man' \\
\hline & & don duine cóir & 'to the just person' \\
\hline \multirow[t]{2}{*}{ Nom. pl. } & \multirow{2}{*}{$\begin{array}{l}\text { Lenition if the noun } \\
\text { ends in a palatalized } \\
\text { consonant, otherwise } \\
\text { radical }\end{array}$} & fir chóra & 'just men' \\
\hline & & máithreacha córa & 'just mothers' \\
\hline Gen. pl. & \multirow[t]{2}{*}{ Radical } & fear cóir & 'of just men' \\
\hline & & máithreacha córa & 'of just mothers' \\
\hline
\end{tabular}


(9) Mutations of attributive adjectives after nouns in Welsh (e.g. mawr 'big')

\begin{tabular}{|l|l|ll|}
\hline Masculine singular & Radical & bwrdd mawr 'a big table' \\
\hline Feminine singular & SM & torth fawr 'a big loaf' \\
\hline Plural & Radical & byrddau mawr 'big tables' \\
& & torthau mawr 'big loaves' \\
\hline
\end{tabular}

(10) Mutations of regular finite verb forms in Irish

a. Radical in present and future tenses without particle

Feicim anois iad.

(feic-)

see-PRES-1SG now them

'I see them now.'

Tiocfaidh Somhairle anocht.

come-FuT S. tonight

(tiocf-)

'Somhairle will come tonight.'

b. Lenition in past, imperfect and conditional tenses without particle (except past autonomous) (cf. (29) in the main text)

Thosaigh sí ag gol. (tosaigh-)

begin-PAST she crying

'She began to cry.'

Deisíodh an rothar.

repair-PAST-AUT the bicycle

(deisigh-)

'The bicycle was repaired.'

Thagadh an galtán gach lá anuraidh.

come-IMPF the steamer every day last-year

'The steamer used to come every day last year.'

Bhrisfí mo chos murach tusa. (bris-)

break-COND-AUT my leg if-not-for you

'My leg would be broken if it weren't for you.'

c. Lenition in all tenses after $a$ (direct relative), $m a ́$ 'if', $n i$ 'not'

an fear a chuireann síol

the man DIR.REL put-PRES seed

'the man who sows seed'

Dúirt sé má chasfadh sé liom go dtabharfadh sé an scéal dom. said he if meet-CONDIT he with-me that give-CONDIT he the story to-me (cas-)

'He said that if he met me he would give me the message.'

Ní fhaca sé mé.

(fac-)

not see-PAST he me

'He did not see me.'

d. Eclipsis in all tenses after $a$ (indirect relative), an (interrogative), cá 'where', dá 'if', go 'that', nach 'that not', mura 'unless', sula 'before'

an gort a geuirfidh sé an síol ann (cuir-)

the field IND.REL put-FUT he the seed in-it

'the field that he will sow the seed in'

An dtagann sé?

INTERR come-PRES he

'Does he come?' 
Cá ndeachaigh sé?

where go-PAST he

(deachaigh-)

'Where did he go?'

dá bhfágainn agat é

if leave-IMPF-1SG with-you it

'if I had left it with you'

ar eagla go mbeinn déanach

(bei-)

for fear that be-CONDIT-1SG late

'for fear that I would be late'

e. Lenition in past tense (except autonomous) after ar (indirect relative; interrogative), cár 'where', gur 'that', murar 'unless', nior 'not', sular 'before'

an gort ar chuir sé an síol ann

the field IND.REL put-PAST he the seed in-it

(cuir-)

'the field that he sowed the seed in'

Cár chuir tú é?

(cuir-)

where put-PAST you it

'Where did you put it?'

Sílim gur bhris an gol air.

think-PRES-1SG that break-PAST the weeping on-him

'I think that he burst into tears.'

murar chaill sé é

if-not lose-PAST he it

'if he didn't lose it'

Níor chreid sé mé.

(creid-)

not believe-PAST he me

'He didn't believe me.'

sular cheannaigh mé an leabhar

(ceannaigh-)

before buy-PAST I the book

'before I bought the book'

(11) Mutations of regular finite verb forms in Welsh

a. $\quad \boldsymbol{S M}$ in affirmative forms after particles $m i / f e$

Mi bryna i 'r tlws i ti.

(pryna)

AFF buy-FUT-1SG I the jewel for you

'I'll buy the jewel for you.'

Fe glywes i 'r newyddion ar y radio bore 'ma.

AFF hear-PAST-1SG I the news on the radio this morning

'I heard the news on the radio this morning.'

(clywes)

b. Optional SM in affirmative forms without mi/fe

Gollais/Collais i 'r tocyn.

lose-PAST-1SG I the ticket

(collais)

'I lost the ticket.'

Allwch/Gallwch chi weld e o fan hyn. (gallwch)

can-PRES-2PL you see-VN him from here

'You can see him from here.' 
c. $\quad \boldsymbol{S} \boldsymbol{M}$ in interrogative forms

Welsoch chi ddyn yn mynd heibio gynnau? see-PAST-2PL you man going past just now

(gwelsoch) 'Did you see a man go past just now?'

d. $\quad \boldsymbol{A M}$ where possible, otherwise $\boldsymbol{S M}$ in negative forms where $n i$ is suppressed (cf. (34) in the main text)

Chododd o mo 'i ben o'r croesair. (cododd) raise-PAST-3SG he NEG his head from the crossword 'He did not raise his head from the crossword.'

Wnes i ddim byd na ddylwn i. (gwnes) do-PAST-1SG I NEG anything NEG-REL ought-1SG I 'I didn't do anything I ought not (to have done).'

e. Radical after hyd 'until, as long as', felly 'so', os 'if', pe 'if' hyd gwelech chi faes chwarae ary dde until see-FUT-2PL you playing field on the right 'until you see a playing field on the right'

felly byddai 'r gallu i siarad Cymraeg yn ddymunol so be-COND-3SG the ability to speak-VN Welsh PRED desirable 'so the ability to speak Welsh would be desirable' (byddai) os daw Freddie i'r parti if come-Fut F. to the party 'if Freddie comes to the party' pe byddai Freddie 'n dod i'r parti if be-CONDF. coming to the party (gwelech) 'if Freddie were coming to the party'

f. $\quad \boldsymbol{S M}$ after pan 'when' pan dynnith hi 'r llun when pull-FUT-3SG she the picture (daw) 'when she takes the picture'

(12) Other proclitic-triggered Lenitions in Irish

a. nouns and names after the vocative particle $a$
a bhean
'O woman'
a fheara
'O men'

b. nouns after certain determiners $\begin{array}{ll}\text { gach uile fhocal } & \text { 'every word' } \\ \text { aon chiall } & \text { 'any sense' }\end{array}$ (ciall)

c. nouns and adjectives after irrealis copular particles ba dhuine mór é 'He was a great man' (duine) ba bhreá é 'it was fine' 
(13) Some syntax-triggered Lenitions in Irish

a. definite genitive NPs (cf. (20) in the main text)

$\begin{array}{lll}\text { muintir Sheáin } & \text { 'Seán's family' } & \text { (Seáin) } \\ \text { mac fhear an tí } & \text { 'the landlord's son' } & \text { (fear) }\end{array}$

b. adjectives and genitive nouns after plural nouns that end in a palatalized consonant

lachain $[\operatorname{lax} \square \mathrm{n} \square$ fhiáine 'wild ducks' (fiáine) buidéil [bidÆ:1] bhainne 'bottles of milk' (bainne)

c. adjectives and genitive nouns after a feminine singular noun spideog bheag 'a small robin' (beag) glac thairní 'a handful of nails' (tairní)

d. adjectives after a noun following a number from 2-19 dhá naomhóg dhubha 'two black coracles'

(14) Other SMs in Welsh

a. nouns and adjectives after the predicative particle $y n$ (does not affect $l l$ and $r h$ ) (cf. (35c) in the main text)

Mae Llundain yn ddinas fawr.

is London PRED city big

'London is a big city.'

Mae Llundain yn fawr.

(mawr)

is London PRED big

'London is big.'

b. nouns and names used vocatively

Dewch fan hyn, blant!

come-IMPV-PL here children

(plant)

'Come here, children!'

c. nouns after adjectives (the marked order)

yr Hen Destament

(Testament)

'the Old Testament'

d. the first word of an adverbial phrase of time or manner

ddwy flynedd yn ôl

'two years ago'

(dwy)

e. a noun after a c-commanding or sister XP (see (21) - (25) in the main text) 


\section{References}

Ball, M. J. \& N. Müller. 1992. Mutation in Welsh. London: Routledge.

Bochner, H. 1993. Simplicity in Generative Morphology. Berlin: Mouton de Gruyter.

Boersma, P. 1998. Functional Phonology: Formalizing the Interactions between Articulatory and Perceptual Drives. Ph.D. dissertation, University of Amsterdam. The Hague: Holland Academic Graphics.

Borsley, R. D. 1997. Mutation and Case in Welsh. Canadian Journal of Lingustics 42: 31-56.

Borsley, R. D. 1999. Mutation and constituent structure in Welsh. Lingua 109: 267-300.

Borsley, R. D. \& M. Tallerman. 1996. Phrases and soft mutation in Welsh. Journal of Celtic Linguistics 5: 1-49.

Broderick, G. 1984-86. A Handbook of Late Spoken Manx. 3 vols. Tübingen: Niemeyer.

Bybee, J. L. 1985. Morphology: A Study of the Relation between Meaning and Form. Amsterdam: Benjamins.

Bybee, J. L. 1988. Morphology as lexical organization. In M. Hammond \& M. Noonan (eds.) Theoretical Morphology: Approaches in Modern Linguistics. San Diego: Academic Press; 119-141.

Bybee, J. L. 2001. Phonology and Language Use. Cambridge: Cambridge University Press.

Christian Brothers 1960. Graiméar Gaeilge na mBráithre Críostaí. Dublin: An Gúm.

Clements, G. N. \& E. V. Hume. 1995. The internal organization of speech sounds. In J. Goldsmith (ed.) The Handbook of Phonological Theory. Oxford: Blackwell; 245-306.

Davidson, L. \& R. Noyer. 1997. Loan phonology in Huave: nativization and the ranking of faithfulness constraints. In B. Agbayani \& S.-W. Tang (eds.), The Proceedings of the Fifteenth West Coast Conference on Formal Linguistics. Stanford: CSLI; 65-79.

de Bhaldraithe, T. 1945/1975. The Irish of Cois Fhairrge, Co. Galway. Dublin: Dublin Institute for Advanced Studies.

de Bhaldraithe, T. 1953/1977. Gaeilge Chois Fhairrge: an Deilbhiocht. Dublin: Dublin Institute for Advanced Studies.

Féry, C. 2003. Final Devoicing and the stratification of the lexicon in German. In J. van de Weijer, V. van Heuren \& H. van der Hulst (eds.) The Phonological Spectrum. Vol. I: Segmental Structure. Amsterdam: John Benjamins; 145-169.

Finck, F. N. 1899. Die araner Mundart: ein Beitrag zur Erforschung des Westirischen. Marburg: Elwert.

Ford, A. \& R. Singh. 1996. Quelques avantages d'une linguistique débarrassée de la morpho(pho)nologie. In R. Singh (ed.) Trubetzkoy's Orphan: Proceedings of the Montréal Roundtable "Morphonology: Contemporary Responses". Amsterdam: Benjamins; 119-139.

Ford, A., R. Singh \& G. Martohardjono. 1997. Pace Pa日ini: Towards a Word-Based Theory of Morphology. New York: Peter Lang.

Gnanadesikan, A. E. 1997. Phonology with Ternary Scales. Ph.D. dissertation, UMass. ROA-195, Rutgers Optimality Archive, http://roa.rutgers.edu/

Green, A. D. 2002. A nonderivational word-based morphology and its phonological consequences. Ms., University of Potsdam. Available online, http://www.ling.uni-potsdam.de/ green/nonderiv.pdf.

Green, A. D. in prep. Phonology Limited. Book ms., University of Potsdam.

Grijzenhout, J. 1995. Irish Consonant Mutation and Phonological Theory. Ph.D. dissertation, Univ. of Utrecht.

Helbig, G. \& J. Buscha. 1991. Deutsche Grammatik: ein Handbuch für den Ausländerunterricht. Leipzig: Langenscheidt - Verlag Enzyklopädie.

Hockett, C. 1958. Two models of grammatical description. In M. Joos (ed.) Readings in Linguistics. 2nd edn. Chicago: University of Chicago Press; 386-399.

Holmer, N. M. 1962. The Dialects of Co. Clare. Part I. Dublin: Royal Irish Academy.

Hughes, A. J. 1986. The Gaelic of Tangaveane and Commeen, County Donegal. Ph.D. dissertation, Queen's University of Belfast.

Hume, E. V. 1992. Front Vowels, Coronal Consonants and their Interaction in Nonlinear Phonology. Ph.D. dissertation, Cornell University.

Itô, J. \& A. Mester 1999. The phonological lexicon. In N. Tsujimura (ed.), The Handbook of Japanese Linguistics. Oxford: Blackwell; 62-100. 
Jackson, K. H. 1955. Contributions to the Study of Manx Phonology. Edinburgh: Nelson and Sons.

Kibre, N. J. 1995. A Model of Mutation in Welsh. M.A. thesis, UCSB. Published 1997, Bloomington: Indiana University Linguistics Club.

King, G. 1993. Modern Welsh: A Comprehensive Grammar. London: Routledge.

Lieber, R. 1987. An Integrated Theory of Autosegmental Processes. Albany: SUNY Press.

Massam, D. 1983. The morphology of Irish mutation. MITWPL 5: 10-29.

McCarthy, J. J. 1988. Feature geometry and dependency: a review. Phonetica 43: 84-108.

McCarthy, J. J. \& A. S. Prince. 1999. Faithfulness and identity in Prosodic Morphology. In R. Kager, H. van der Hulst \& W. Zonneveld (eds.) The Prosody-Morphology Interface. Cambridge: Cambridge University Press; 218-309.

Mhac an Fhailigh, É. 1968. The Irish of Erris, Co. Mayo. Dublin: Dublin Institute for Advanced Studies.

Ní Chiosáin, M. 1991. Topics in the Phonology of Irish. Ph.D. dissertation, UMass.

Ó Cuív, B. 1944. The Irish of West Muskerry, Co. Cork. Dublin: Dublin Institute for Advanced Studies.

Ó Dónaill, N., ed. 1977. Foclóir Gaeilge-Béarla. Dublin: An Gúm.

Ó Duibhín, C. 2003. Tobar na Gaedhilge, version 1.1. Searchable database. Available online, http://www.smo.uhi.ac.uk/ oduibhin/tobar/.

Ó Sé, D. 2000. Gaeilge Chorca Dhuibhne. Dublin: Insitiúid Teangeolaíochta Éireann.

Ó Searcaigh, S. 1925. Foghraidheacht Ghaedhilge an Tuaiscirt. Belfast: Browne \& Nolan.

Ó Siadhail, M. 1989. Modern Irish: Grammatical Structure and Dialectal Variation. Cambridge: Cambridge University Press.

Prince, A. \& P. Smolensky. 1993. Optimality Theory: Constraint Interaction in Generative Grammar. Rutgers University Center for Cognitive Science Technical Report \#2. Revised version (2002) available as ROA-537, Rutgers Optimality Archive, http://roa.rutgers.edu/

Pyatt, E. J. 1997. An Integrated Model of the Syntax and Phonology of Celtic Mutation. Ph.D. dissertation, Harvard University.

Quiggin, E. C. 1906. A Dialect of Donegal. Cambridge: Cambridge University Press.

Roberts, I. G. 1997. The syntax of direct object mutation in Welsh. Canadian Journal of Linguistics 42: $141-168$.

Roberts, I. G. in press. Principles and Parameters in a VSO Language: A Case Study in Welsh. Oxford: Oxford University Press.

Sagey, E. 1986. The Representation of Features and Relations in Nonlinear Phonology. Ph.D. dissertation, MIT. Published 1991, New York: Garland.

Singh, R. 1987. Well-formedness conditions and phonological theory. In W. U. Dressler, H. C. Luschützky, O. E. Pfeiffer \& J. R. Rennison (eds.) Phonologica 1984. Cambridge: Cambridge University Press; 273-285.

Singh, R. 1996. Natural Phono(morpho)logy: a view from the outside. In B. Hurch \& R. A. Rhodes (eds.) Natural Phonology: The State of the Art. Berlin: Mouton de Gruyter; 1-38.

Sommerfelt, A. 1929. South Armagh Irish. Norsk Tidsskrift for Sprogvidenskap 2: 107-191.

Sommerfelt, A. 1965. The phonemic structure of the dialect of Torr, Co. Donegal. Lochlann 3: 237-254.

Spencer, A. 1998. Morphophonological operations. In A. Spencer \& A. M. Zwicky (eds.) The Handbook of Morphology. Oxford: Blackwell; 123-143.

Stenson, N. 1990. Phrase structure congruence, government, and Irish-English code-switching. In R. Hendrick (ed.) Syntax and Semantics, Volume 23: The Syntax of the Modern Celtic Languages. San Diego: Academic Press. 167-197.

Tallerman, M. 1998. The uniform Case-licensing of subjects in Welsh. The Linguistic Review 15: 69-133.

Tallerman, M. 1999. Welsh soft mutation and marked word order. In M. Darnell, E. Moravcsik, F. Newmeyer, M. Noonan \& K. Wheatley (eds.) Functionalism and Formalism in Linguistics. Vol. 2: Case studies. Amsterdam: John Benjamins; 277-294.

Tallerman, M. 2003. The syntax of Welsh "direct object mutation" revisited. Talk presented at the Fourth Celtic Linguistics Conference, University of Cambridge, 1 September 2003.

Thorne, D. A. 1993. A Comprehensive Welsh Grammar. Oxford: Blackwell. 


\section{Antony Dubach Green}

Zwicky, A. 1984. Welsh soft mutation and the case of object NPs. In J. Drogo, V. Mishra \& D. Testen (eds.) Papers from the Twentieth Regional Meeting of the Chicago Linguistic Society. Chicago: Chicago Linguistic Society; 387-402. 